\title{
Molecular cloning, characterization, genomic organization and promoter analysis of the $\alpha$ 1,6-fucosyltransferase gene (fut8) expressed in the rat hybridoma cell line YB2/0
}

Béatrice Teylaert ${ }^{1,4}$, Edwige Meurice ${ }^{1,4}$, Marie Bobowski ${ }^{2,3,4}$, Anne Harduin-Lepers ${ }^{2,3,4}$, Christine Gaucher ${ }^{1}$, Alexandre Fontayne ${ }^{1}$, Sylvie Jorieux ${ }^{1}$, Philippe Delannoy ${ }^{2,3,4^{*}}$

\begin{abstract}
Background: The rat hybridoma cell line YB2/0 appears a good candidate for the large-scale production of low fucose recombinant mAbs due to its lower expression of fut8 gene than other commonly used rodent cell lines. However, important variations of the fucose content of recombinant mAbs are observed in production culture conditions. To improve our knowledge on the YB2/0 fucosylation capacity, we have cloned and characterized the rat fut8 gene.

Results: The cDNAs encoding the rat $\alpha 1,6$-fucosyltransferase (FucT VIII) were cloned from YB2/0 cells by polymerase chain reaction-based and 5' RNA-Ligase-Mediated RACE methods. The cDNAs contain an open reading frame of 1728 bp encoding a 575 amino acid sequence showing $94 \%$ and $88 \%$ identity to human and pig orthologs, respectively. The recombinant protein expressed in COS-7 cells exhibits a $\alpha 1,6$-fucosyltransferase activity toward human asialo-agalacto-apotransferrin. The rat fut8 gene is located on chromosome $6 \mathrm{q}$ and spans over 140 kbp. It contains 9 coding exons and four 5 '-untranslated exons. FISH analysis shows a heterogeneous copy number of fut8 in YB2/0 nuclei with $2.8 \pm 1.4$ mean copy number. The YB2/0 fut8 gene is expressed as two main transcripts that differ in the first untranslated exon by the usage of distinct promoters and alternative splicing. Luciferase assays allow defining the minimal promoting regions governing the initiation of the two transcripts, which are differentially expressed in YB2/0 as shown by duplex Taqman QPCR analysis. Bioinformatics analysis of the minimal promoter regions upstream exons E-2 and E-3, governing the transcription of T1 and T2 transcripts, respectively, evidenced several consensus sequences for potential transcriptional repressors. Transient transfections of Rat2 cells with transcription factor expression vectors allowed identifying KLF15 as a putative repressor of T1 transcript in Rat2 cells.
\end{abstract}

Conclusion: Altogether, these data contribute to a better knowledge of fut8 expression in YB2/0 that will be useful to better control the fucosylation of recombinant mAbs produced in these cells.

\section{Background}

Several independent studies have clearly shown that effector functions of recombinant therapeutic IgG are directly dependent on the glycosylation of the constant region (Fc) [1-3]. Each heavy chain of IgG1 Fc fragment contains a single $\mathrm{N}$-glycosylation site substituted by a

\footnotetext{
* Correspondence: philippe.delannoy@univ-lille1.fr

${ }^{2}$ Univ. Lille Nord de France, F-59000 Lille, France

Full list of author information is available at the end of the article
}

biantennary complex glycan. The minimal core structure is a heptasaccharide $\left(\mathrm{GlcNAc}_{2} \mathrm{Man}_{3} \mathrm{GlcNAc}_{2}\right)$ potentially substituted by galactose ( $\mathrm{Gal})$, bisecting $\mathrm{N}$-acetylglucosamine (GlcNAc), sialic acid (Neu5Ac) and/or fucose (Fuc) residue $\alpha 1,6$-linked to the first GlcNAc attached to Asn297 of IgG heavy chains [4].

IgG Fc oligosaccharides determine the overall conformation of the Fc fragment [5] and modulate the capacity of IgG to interact with Fc $\gamma \mathrm{R}$ [6]. Therefore, it is clearly established that the Antibody-Dependent Cellular

C Biomed Central

(C) 2011 Teylaert et al; licensee BioMed Central Ltd. This is an Open Access article distributed under the terms of the Creative Commons Attribution License (http://creativecommons.org/licenses/by/2.0), which permits unrestricted use, distribution, and reproduction in any medium, provided the original work is properly cited. 
Cytotoxicity (ADCC) is dependent on appropriate glycosylation of the Fc region of mAbs (for review [7]). The specific role in ADCC of each monosaccharide substituting the core structure has been studied in details, showing the key role of the core fucose in cellular toxicity [8-10]. Low fucose IgG1 (10-20\%) exhibit a higher ADCC activity compared to highly fucosylated IgG (80-90\%) either in vitro [8] or in vivo [10].

The most widely used recombinant antibodies are produced by rodent mammalian cell lines with intrinsic fucosyltransferase activity (e.g., Chinese hamster ovary (CHO), mouse myeloma and hybridoma cell lines). Therefore, almost all licensed therapeutic antibodies developed to date are heavily fucosylated $[11,12]$, which results in a non-optimized ADCC. Reducing the $\alpha 1,6$-fucose rate of IgG Fc has been a challenge over the last few years to provide maximum efficiency to recombinant mAbs.

In mammals, the GDP-L-Fuc: $\mathrm{N}$-acetyl- $\beta$-D-glucosaminide $\alpha 1,6$-fucosyltransferase ( $\alpha 1,6$-FucT) is the only enzyme able to catalyze the transfer of a Fuc residue in $\alpha 1,6$-linkage to the first GlcNAc residue of N-glycan chains [13]. GDP-fucose, the unique donor substrate of fucosyltransferases, is synthesized in the cytoplasm from GDP-mannose, via three enzymatic reactions carried out by two proteins: GDP-mannose 4,6-dehydratase (GMD) and GDP-4-keto-6-deoxymannose 3,5-epimerase, 4 -reductase (FX) [14,15]. The GDP-fucose is then transported into the lumen of the Golgi apparatus by a GDP-fucose transporter (GFT) located at the Golgi membrane [16], where it serves as a substrate in the synthesis of fucosylated glycoconjugates $[15,17,18]$. $\alpha 1,6$-FucT is encoded by the fut 8 gene and different strategies targeting fut 8 or other fucose-related genes have been developed to reduce the fucosylation capacity of recombinant mAb producing cells. The fut8 gene [19], the GMD gene [20], or both [21] have been knockdown in $\mathrm{CHO}$ cells, generating completely non-fucosylated recombinant mAbs. Fut8 siRNA was also used for engineering $\mathrm{CHO}$ cells to upgrade effector function of produced antibodies [22] and recently, short-hairpin-RNA has been developed for the silencing of fut8 in $\mathrm{CHO}$, resulting in an enhanced antibody immune effector function [23]. Glycosylation inhibitors were also proposed to enhance cellular toxicity of recombinant IgG [24] and lectin-affinity chromatography techniques have been applied to enrich in non-fucosylated species the produced recombinant mAbs [25].

Alternative cell lines have been tested for the reduction of core fucose on recombinant mAbs. The Lec13 mutant $\mathrm{CHO}$ cell line, partially deficient in GMD [26] was used to produce human IgG1 that were deficient in fucose [8]. As an alternative, the rat hybridoma cell line YB2/0 was proposed as a good candidate for the largescale production of low fucose IgG [9]. Thus, this cell line has a very good capacity of IgG biosynthesis and its fucose transfer capacity is much lower than the other rodent cell lines commonly used [27]. However, important variations of the fucose content has been observed for the producing clones in production culture conditions [28], indicating that a better knowledge of the capacity of the YB2/0 fucosylation machinery is required for optimizing the fucosylation of recombinant mAbs at the production level. Thus, we have analyzed the fucosylation capacity of YB2/0 and we report here the molecular cloning of the rat fut8 cDNA, the futs gene organization including 5 -untranslated exons and transcription start-sites, the number of fut 8 copies in YB2/0 nuclear genome and the analysis of two promoter regions (P1 and P2) governing fut8 transcription in these cells. In particular, we identified several potential repressor binding sequences in both minimal promoters and showed that KLF15 can repress the activity of P1 promoter region.

\section{Methods}

\section{Cell culture}

The rat cell line YB2/0 was obtained from American Type Culture Collection (Manassas, VA, http://www.atcc. org; catalog $\left.\mathrm{n}^{\circ} \mathrm{CRL}-1662\right)$ and grown in $\mathrm{EMS}^{\mathrm{m}}$ medium (optimized and patented culture medium developed by the Laboratoire Français du Fractionnement et des Biotechnologies, Lille, France) supplemented with 5\% heat inactivated FCS (Invitrogen, Carlsbad, CA, USA) at $37^{\circ} \mathrm{C}$ under $5 \% \mathrm{CO}_{2}$. The rat Rat2 cell line (ATCC $n^{\circ} \mathrm{CRL}-$ 1764) and COS-7 (ATCC n ${ }^{\circ}$ CRL-1651) were cultivated in Dulbecco's modified Eagle's medium, DMEM, (BioWittaker, Lonza, Brussels, Belgium) supplemented with $10 \%$ heat-inactivated FCS and $2 \mathrm{mM}$ of L-glutamine (Lonza, Brussels, Belgium) at $37^{\circ} \mathrm{C}$ in $5 \% \mathrm{CO}_{2}$.

\section{Bio-informatics analysis}

In silico analysis was performed with BLAST analysis of rat genomic and expressed sequence tags (EST) divisions of the NCBI databases http://www.ncbi.nlm.nih. gov/sites/entrez. Multiple sequence alignments were performed with the Clustal W program http://www.ebi. ac.uk/Tools/clustalw2/index.html. Expasy site http:// www.expasy.ch was used for protein analysis. Analysis of minimal promoter regions was performed with Matinspector $2.2 \mathrm{http}: / /$ www.genomatix.de using TRANSFAC matrices 4.0 [29] with "core similarity: 0.9" and "matrices similarity: Optimized". Filters corresponding to myeloid and lymphoid cells were used to screen specific cells transcription factors.

\section{RNA isolation and cDNA synthesis}

YB2/0 cells were used as source of RNA. Total RNA was extracted using the Nucleospin RNA II (Macherey- 
Nagel, Düren, Germany) according to the protocol provided by the manufacturer. Total RNA $(2 \mu \mathrm{g})$ was reverse-transcribed using first strand cDNA synthesis kit (Amersham Biosciences, Freiburg, Germany).

\section{Molecular cloning of rat $\alpha 1,6$ fucosyltransferase cDNA}

The $\alpha 1,6$-fucosyltransferase open reading frame was amplified from $1 \mu \mathrm{L}$ of YB2/0 cells cDNA with the primer pair 5F8r2: 5'-agtcgccacaggattacc-3'and 3F8r2: 5'atctgcttagccgagatg- $3^{\prime}$ at $94^{\circ} \mathrm{C}$ for $2 \mathrm{~min}$, followed by 30 cycles $\left(94^{\circ} \mathrm{C}\right.$, for $30 \mathrm{sec} ; 50^{\circ} \mathrm{C}$ for $45 \mathrm{sec} ; 68^{\circ} \mathrm{C}$ for $2 \mathrm{~min}$ $10 \mathrm{sec}$ ) and an extension step of $10 \mathrm{~min}$ at $68^{\circ} \mathrm{C}$. The PCR product was cloned into the pCR II-Blunt TOPO vector (Invitrogen, Carlsbad, CA, USA). The encoding sequence was isolated by digestion of the vector using HindIII and XbaI restriction sites. The purified fragment was subcloned into pcDNA3.1 vector (Invitrogen, Carlsbad, CA, USA) digested by HindIII and Xbal. The resultant plasmid was designed pcDNA-Fut8. COS-7 cells were transiently transfected with pcDNA-Fut8 or the empty plasmid using lipofectamine (Invitrogen, Carlsbad, CA, USA) according to the manufacturer's instructions. Cells were harvested $48 \mathrm{~h}$ after transfection.

\section{Preparation of the asialo-agalacto apotransferrin acceptor substrate}

After dialysis against sodium acetate buffer $(50 \mathrm{mM}, \mathrm{pH}$ 7.5), $5 \mathrm{mg}$ of human apotransferrin (Sigma-Aldrich, Lyon, France) were incubated with $120 \mathrm{mU}$ of Arthrobacter ureafasciens neuraminidase (Sigma-Aldrich, Lyon, France) and $50 \mathrm{mU}$ of Escherichia Coli $\beta$-galactosidase (Sigma-Aldrich, Lyon, France) at $37^{\circ} \mathrm{C}$ for $24 \mathrm{~h}$ in a final volume of $10 \mathrm{~mL}$. After $4 \mathrm{~h}$ of dialysis against water, asialo-agalacto-apotransferrin was freeze-dried. The absence of galactose and sialic acid residues was controlled by GC-MS.

\section{Fucosyltransferase assay}

COS-7 cells, transiently transfected with pcDNA-Fut8 or the empty plasmid, were harvested by scrapping in a 4 mM EDTA solution, pelleted by low-speed centrifugation and resuspended in lysis buffer $(150 \mathrm{mM} \mathrm{NaCl}, 50$ $\mathrm{mM}$ Tris- $\mathrm{HCl}, \mathrm{pH} 7.5,1 \%$ Triton X-100), containing a cocktail of proteases and phosphatase inhibitors (Roche, Basel, Switzerland). The protein concentration of protein extracts was determined with the Micro $\mathrm{BCA}^{\mathrm{Tm}}$ Protein Assay Reagent kit (Thermo Fisher Scientific Inc, Rockford, IL, USA).

Enzyme assays were performed with $20 \mu \mathrm{L}$ of protein extract $(140 \mu \mathrm{g} / \mathrm{mL}), 70 \mathrm{mM}$ cacodylate buffer $(\mathrm{pH} 7.2)$ $10 \mathrm{mM}$ L-fucose, $6 \mu \mathrm{M}$ GDP- $\left[{ }^{14} \mathrm{C}\right]$-L-fucose $(299 \mathrm{mCi} /$ mmol, Amersham Biosciences, Pantin, France), $10 \mathrm{mM}$ GDP-fucose and $100 \mu \mathrm{g}$ asialo-agalacto human apotransferrin as acceptor substrate, in a final volume of $50 \mu \mathrm{L}$, at $30^{\circ} \mathrm{C}$ for $4 \mathrm{~h}$. The reaction was stopped with $150 \mu \mathrm{L}$ of RT water, precipitated with $1 \mathrm{~mL}$ of $5 \%$ phosphotungstic acid and processed for scintillation counting. The transfer of $\left[{ }^{14} \mathrm{C}\right]$-fucose is expressed in cpm.

\section{Amplification of 5'cDNA ends by RNA-Ligase-Mediated RACE (RLM-RACE)}

RLM-RACE [30] amplifications were performed using the GeneRacer kit (Invitrogen, Carlsbad, CA, USA) according to the manufacturer's instructions. Initial reverse transcription was performed with the oligo $\mathrm{dT}$ primer using $5 \mu \mathrm{g}$ of total RNA. After synthesis of the first strand cDNA, PCR were performed with the GeneRacer5'Primer from the kit and a gene-specific primer 3F8Race3 5'-cttccegtagccgtccctggtcaa- 3 ' at $94^{\circ} \mathrm{C}$ for 2 min, followed by 38 cycles $\left(94^{\circ} \mathrm{C}\right.$, for $45 \mathrm{sec} ; 57^{\circ} \mathrm{C}$ for 45 sec; $68^{\circ} \mathrm{C}$ for $1 \mathrm{~min} 45 \mathrm{sec}$ ) and an extension step of 10 min at $68^{\circ} \mathrm{C}$. Nested PCR were performed with the GeneRacer5'Primer Nested provided in the kit and a genespecific primer 3F8Race4 5'-actcagccattcgcctcaagtcttc-3', using $2 \mu \mathrm{L}$ of the first PCR amplification and the same conditions as the first PCR. PCR amplifications were performed with Taq AccuPrime (Invitrogen, Carlsbad, CA, USA) according to the provider's instructions. Nested-PCR products were size separated by Agarose gel electrophoresis, subcloned into pCR4-TOPO vector (Invitrogen, Carlsbad, CA, USA) and sequenced by Genoscreen (Lille, France).

\section{Reverse transcription and quantitative PCR}

The expression of the transcripts 1 and 2 was analyzed by quantitative real-time PCR. $2 \mu$ g of total RNA was reverse transcribed with poly- $T$ oligonucleotide using Affinity script QPCR cDNA Synthesis kit (Agilent technologies, Santa Clara, CA, USA) according to the protocol provided by the manufacturer. Parallel reactions without SuperScript (RT controls) were performed to assess the degree of contaminating genomic DNA.

Duplex Taqman ${ }^{\text {mi }}$ QPCR and subsequent analysis were performed using the Mx-4000 Quantitative System (Stratagene, Amsterdam, the Nederlands). Primers and probes were designed using Primer Express software (Applied Biosystems, Carlsbad, CA, USA) (Table 1). The probes were MGB Taqman $^{\text {ta }}$ probes synthesized by Applied Biosystems. The Transcript 1 (T1) and Transcript 2 (T2) probes were FAM-labeled and the reference gene HPRT probe was VIC-labeled. PCR reactions were performed with $12.5 \mu \mathrm{L}$ of the Quantitect Multiplex PCR kit (Qiagen, Courtaboeuf, France), $0.4 \mu \mathrm{M}$ of each primer, $0.2 \mu \mathrm{M}$ of HPRT Taqman ${ }^{\mathrm{Tw}}$ probe, $0.2 \mu \mathrm{M}$ of $\mathrm{T} 1$ or $\mathrm{T} 2 \mathrm{Taqman}^{\mathrm{TM}}$ probe and $2 \mu \mathrm{L}$ of cDNA in a final volume of $25 \mu \mathrm{L}$. After $95^{\circ} \mathrm{C}$ for $15 \mathrm{~min}, 40 \mathrm{PCR}$ cycles were performed as follows: $95^{\circ} \mathrm{C}$ for $1 \mathrm{~min}, 60^{\circ} \mathrm{C}$ for $1 \mathrm{~min}$. Assays for each transcript were performed in 
Table 1 Probes and primer sequences used for $\operatorname{TaqMan}^{\mathrm{TM}}$ quantitative PCR experiments

\begin{tabular}{lll}
\hline Target & $\begin{array}{l}\text { Forward Primer } \\
\text { Reverse Primer }\end{array}$ & Probe \\
\hline Transcript T1 & $\begin{array}{l}5^{\prime} \text {-cgcgggctgctgttc-3' } \\
\text { 5'-ataataatggaaaggactt }\end{array}$ & 5'-ccctggtggcgtt-3' $^{\prime}$ \\
& gatcttgg-3' & \\
Transcript T2 & $\begin{array}{l}5^{\prime} \text {-ccgcttagctcgcctcta-3' } \\
\text { 5'-aggactagatcttggatgaaaacg-3' }\end{array}$ & 5'-agtccttcggeccacg-3' $^{\prime}$ \\
HPRT & $\begin{array}{l}\text { 5'-tgtacttggctttccactttcg-3' } \\
\text { 5'-tgcccttgactataatgagcacttc-3' }\end{array}$ & $\begin{array}{l}5^{\prime} \text {-atgacacaaacatg } \\
\text { attca-3' }\end{array}$ \\
\hline
\end{tabular}

triplicate and real-time PCR amplification was repeated 3 times. Relative amounts of mRNAs were based on standard curves prepared by a serial dilution of control YB2/0 cDNA.

\section{FISH (Fluorescence In Situ Hybridization)}

The YB2/0 cell line was grown in EMS ${ }^{\mathrm{TM}}$ medium supplemented with $5 \%$ heat inactivated FCS for 72 hours prior cell fixation and in situ hybridization. Primary rat lymphocytes were isolated from rat blood following standard procedures. The probes used for the FISH analysis were designed and prepared as follow: fut8 and a non relevant probe (NRP) for rat genome were designed by using respectively 3 and 2 BACs. Bacteria were amplified in LB Broth, and then BACs were purified on Anion Exchange columns (Qiagen, Courtaboeuf, France) following the manufacturer's instructions. Probes labeling was then performed using the ARES Alexa Fluor 488 Labeling kit (Invitrogen, Carlsbad, CA, USA), while the purification was done with the PureLink PCR Purification Kit (Invitrogen, Carlsbad, CA, USA). To avoid probes unspecific binding to repetitive DNA sequences, samples were precipitated with $1 \mu \mathrm{g}$ of Rat Hybloc competitor DNA (Insight Biotechnology Limited, Wembley, UK).

The FISH assays were carried out in standard conditions. Fluorescent DNA probes and samples were denatured for $10 \mathrm{~min}$ at $73^{\circ} \mathrm{C}$. The hybridizations were performed overnight at $37^{\circ} \mathrm{C}$ in a humidified chamber. The coverslides were then washed 3 times at $45^{\circ} \mathrm{C}$ with $50 \%$ formamide in SSC2X, one time in SSC2X before a final wash in SSC2X, 0.1\% NP-40. Finally, nuclei were counterstained for $30 \mathrm{~min}$ at $4^{\circ} \mathrm{C}$ in darkness, with DAPI III/mountain medium (Abbott-France, Rungis, France) before observation under an epifluorescence microscope (Olympus, BX61) using appropriated fluorescent filters.

Raw data of the FISH analysis were compared with statistical methods by using SPSS 13.0 software. Data were analyzed under the normality test Kolmogorov-Smirnov, before applying non parametric Kruskal-Wallis and U-Mann Whitney tests. Statistical differences between samples were considered significant when $\mathrm{p}<0.05$.
Construction of reporter plasmids for luciferase assays Genomic DNA of YB2/0 cells were prepared with Nucleospin Extract II kit (Macherey Nagel, Düren, Germany) following manufacturer's instructions. To analyze the T1 transcript promoter region, the genomic sequence located between the $-1438 \mathrm{bp}$ and $-411 \mathrm{bp}$ upstream the ATG was amplified by PCR using the primer pair: FP1.8: 5' -cgtggcaagcttccctaacgccccttacccg-3' and FP1.7: 5' -ctccetggtacctccgtactcaataaacttccgcc-3' introducing HindIII and KpnI restriction sites (underlined in the oligonucleotide sequences), respectively. The PCR product was subcloned into pGL3-basic vector (pGL3b, Promega, Madison, USA) upstream of the firefly luciferase gene at HindIII/KpnI sites. The resulting plasmid was designed pGL3(-1438/-411). This PCR fragment was submitted to 5' and 3' deletions using natural restriction enzyme sites and cloned in pGL3b to generate various vectors (Table 2 ).

To analyze the T2 transcript promoter region, the genomic region of 1,000 bp upstream exon E-3 was amplified from YB2/0 cells genomic DNA using primers FKO11 5'-ccgggctagcacattccaccctgactcctaa-3' and FKO12 5'-ccggctcgaggtttcctacccgctcgcactcg-3' creating NheI and XhoI restriction sites (underlined in the oligonucleotide sequences), respectively. The amplified fragment was subcloned into pGL3b. The plasmid was called pGL3(-1399/-404). Following the same strategy, nested PCR fragments were subcloned into pGL3b upstream the firefly luciferase gene at NheI/XhoI sites (Table 3). The different constructions were sequenced to ensure the absence of mutations.

\section{Transient transfections and luciferase assay}

Rat2 cells were transiently transfected using lipofectamine (Invitrogen, Carlsbad, CA, USA) according to the manufacturer's instructions, using $1 \mu \mathrm{g} / \mathrm{mL}$ of pGL3b construction and $10 \mathrm{ng} / \mathrm{mL}$ of control Renilla plasmid in OptiMEM medium (Invitrogen, Carlsbad, CA, USA). After $6 \mathrm{~h}$, the medium was changed for fresh cell

\section{Table 2 Reporter plasmids for T1 transcript luciferase} assays

\begin{tabular}{lll}
\hline Digestion & Position of the fragment & Vector name \\
\hline Apal, HindIII & $-1205 /-411$ & pGL3(-1205/-411) \\
BseRl, HindIII & $-1004 /-411$ & pGL3(-1004/-411) \\
Nhel, HindIII & $-892 /-411$ & pGL3(-892/-411) \\
Msel, HindIII & $-598 /-411$ & pGL3(-598/-411) \\
Kpnl, Pvul & $-1438 /-451$ & pGL3(-1438/-451) \\
Kpnl, Pvul & $-1205 /-451$ & pGL3(-1205/-451) \\
Nhel, Pvul & $-892 /-451$ & pGL3(-892/-451) \\
Kpnl, Msel & $-1438 /-598$ & pGL3(-1438/-598) \\
Kpnl, Msel & $-1205 /-598$ & pGL3(-1205/-598) \\
Nhel, Msel & $-892 /-598$ & pGL3(-892/-598) \\
\hline
\end{tabular}


Table 3 Primers used for the construction of plasmids for T2 transcript luciferase assays

\begin{tabular}{|c|c|c|}
\hline Forward primer & Reverse primer & Vector name \\
\hline $\begin{array}{l}\text { FKO13-Nhel } \\
\text { 5'-ccgggctagcgtttatttccaacagagtacacgactc-3' }\end{array}$ & $\begin{array}{l}\text { FKO12-Xhol } \\
\text { 5'-ccggctcgaggtttcctacccgctcgcactcg-3' }\end{array}$ & pGL3(-1233/-404) \\
\hline $\begin{array}{l}\text { FKO15-Nhel } \\
5^{\prime} \text {-ccgggctagccaggtgaggagctgctgaaggcacagac-3' }\end{array}$ & $\begin{array}{l}\text { FKO12-Xhol } \\
\text { 5'-ccggctcgaggtttcctacccgctcgcactcg-3' }\end{array}$ & pGL3(-998/-404) \\
\hline $\begin{array}{l}\text { FKO17-Nhel } \\
5^{\prime} \text {-ccgggctagcgtcttgagggcagcttttctactcagc-3' }\end{array}$ & $\begin{array}{l}\text { FKO12-Xhol } \\
\text { 5'-ccggctcgaggtttcctacccgctcgcactcg-3' }\end{array}$ & pGL3(-720/-404) \\
\hline $\begin{array}{l}\text { FKO11-Nhel } \\
5^{\prime} \text {-ccgggctagcacattccacccctgactcctaagaccaac-3' }\end{array}$ & $\begin{array}{l}\text { FKO14-Xhol } \\
5^{\prime} \text {-ccggctcgaggtcgccggccgggtgccaccggggccaatc-3' }\end{array}$ & pGL3(-1399/-537) \\
\hline $\begin{array}{l}\text { FKO13-Nhel } \\
\text { 5'-ccgggctagcgtttatttccaacagagtacacgactc-3' }\end{array}$ & $\begin{array}{l}\text { FKO14-Xhol } \\
5^{\prime} \text {-ccggctcgaggtcgccggccgggtgccaccggggccaatc-3' }\end{array}$ & pGL3(-1233/-537) \\
\hline $\begin{array}{l}\text { FKO15-Nhel } \\
\text { 5'-ccgggctagccaggtgaggagctgctgaaggcacagac-3' }\end{array}$ & $\begin{array}{l}\text { FKO14-Xhol } \\
5^{\prime} \text {-ccggctcgaggtcgecggccgggtgccaccggggecaatc-3' }\end{array}$ & pGL3(-998/-537) \\
\hline $\begin{array}{l}\text { FKO17-Nhel } \\
\text { 5'-ccgggctagcgtcttgagggcagcttttctactcagc-3' }\end{array}$ & $\begin{array}{l}\text { FKO14-Xhol } \\
5^{\prime} \text {-ccggctcgaggtcgccggccgggtgccaccggggccaatc-3' }\end{array}$ & pGL3(-720/-537) \\
\hline
\end{tabular}

culture medium and incubated for $48 \mathrm{~h}$ at $37^{\circ} \mathrm{C}$ in $5 \%$ $\mathrm{CO}_{2}$. Cells were then washed one time with PBS, lysed in $150 \mu \mathrm{L}$ of Passive Lysis Buffer (PLB, Dual Luciferase Reporter Assay System, Promega, Madison, USA) and $20 \mu \mathrm{L}$ of lysate were used for luciferase Reporter Assay System. Luminescence was measured with the Centro luminometer (Berthold Technologies, Bad Wildbad, Germany).

The YB2/0 cells were transiently transfected with Cell line Nucleofector ${ }^{\circledR}$ kitV (Amaxa Lonza, Verviers, Belgium) according to manufacturer's instructions. $2 \times 10^{6}$ cell pellets were resuspended in $100 \mu \mathrm{L}$ of Nucleofector ${ }^{\mathbb{B}}$ kitV solution. The cell suspensions were mixed with $2 \mu \mathrm{g}$ of pGL3b construction and $20 \mathrm{ng}$ of control Renilla plasmid. The mixtures were transferred into an Amaxa cuvette and submitted to nucleofection using the T-020 program. Cells were plated on 6-well plates with $2 \mathrm{~mL}$ of culture medium and incubated for $24 \mathrm{~h}$ at $37^{\circ} \mathrm{C}$ in $5 \% \mathrm{CO}_{2}$. Cells were then centrifuged $5 \mathrm{~min}$ at 1,200 rpm, washed one time with PBS and processed for luciferase reporter assay as described for Rat2.

The pcDNA3.1 expression vector encoding the human KLF15 transcription factor (pcDNA-hKLF15) was kindly provided by Dr. Otteson, College of Optometry, University of Houston, USA. For transfection of Rat2 cells, 25 to $500 \mathrm{ng} / \mathrm{mL}$ of pcDNA-hKLF15 vector were added to the lipofection mix.

\section{Nuclear and cytoplasm protein extraction, Western blotting analysis}

48 hours after transfection with KLF15 vector, Rat2 cells were lysed on ice in a hypotonic buffer (Hepes $10 \mathrm{mM}$, $\mathrm{MgCl}_{2} 1,5 \mathrm{mM}, \mathrm{KCl} 10 \mathrm{mM}, \mathrm{pH}$ 7.9) supplemented with $0.125 \%$ NP-40 and protease cocktail inhibitors (Roche, Meylan, France). The lysate was centrifuged for $5 \mathrm{~min}$ at $10,000 \mathrm{~g}$ and the cytosolic fraction was obtained in the supernatant. The pellet corresponding to the nuclear fraction was lysed with hypertonic buffer
(Hepes $20 \mathrm{mM}, \mathrm{MgCl}_{2} 1.5 \mathrm{mM}$, EDTA $0.2 \mathrm{mM}, \mathrm{NaCl}$ $0.5 \mathrm{M}$, glycerol $25 \%$, pH 7.9) supplemented with protease cocktail inhibitors on ice during two hours. The protein concentration of both fractions was determined with the Micro BCA ${ }^{\text {mm }}$ Protein Assay Reagent kit (Pierce, Rockford, IL, USA). $20 \mu \mathrm{g}$ of total proteins were boiled for $10 \mathrm{~min}$ in reducing Laemmli sample buffer and resolved by SDS-PAGE on $8 \%$ mini-gels (Bio-Rad, Richmond, USA). After transfer onto a nitrocellulose membrane ( $80 \mathrm{~mA}$ overnight), blocking was performed using TBS (Tris Buffer Saline) containing 0.05\% Tween 20 and $5 \%(\mathrm{w} / \mathrm{v})$ non-fat dried milk for one hour at room temperature (RT). Incubations with $2.5 \mu \mathrm{g} / \mathrm{mL}$ anti-KLF15 $\mathrm{mAb}$ (AbCam, Cambridge, UK) or $0.04 \mu \mathrm{g} / \mathrm{mL}$ antiactin mAb (Santa Cruz Biotechnology Inc., Europe) were performed one hour at RT in TBS, $0.05 \%$ Tween 20 and $5 \%(\mathrm{w} / \mathrm{v})$ non-fat dried milk. After washing, membranes were incubated for $1 \mathrm{~h}$ at RT with $1 / 15,000$ dilution in TBS, $0.05 \%$ Tween 20 and $5 \%(\mathrm{w} / \mathrm{v})$ non-fat dried milk of horseradish peroxidase conjugated antigoat IgG for KLF15 or anti-rabbit IgG for actin. Membranes were finally washed three times for $10 \mathrm{~min}$ in TBS, $0.05 \%$ Tween 20 and detection was achieved using enhanced chemiluminescence $\left(\mathrm{ECL}+{ }^{\circledR}\right.$ advanceWestern blotting detection reagents, Amersham Biosciences, Little Chalfont, Buks, U.K.).

\section{Electrophoretic mobility shift assays (EMSA)}

Biotin 5' end-labeled (-892/-451) promoter DNA probe was obtained by PCR from pGL3(-892/-451) plasmid using biotin 5' end-labeled primers (forward P1 min 5'gctagcgccggcccgaggct-3', reverse P1 min 5'cgatcggcgccgtcccccgt-3'). Rat2 cells nuclear extract was prepared as previously described. EMSA was performed with a Lightshift ${ }^{\circledR}$ Chemiluminescent EMSA kit (Thermo Scientific, Waltham, USA) as follows. Nuclear extract ( $3 \mu \mathrm{g}$ protein) was incubated for $20 \mathrm{~min}$ at room temperature in $1 \times$ binding buffer, $2.5 \%$ glycerol, $5 \mathrm{mM}$ 
$\mathrm{MgCl}_{2}, 50 \mathrm{ng} / \mu \mathrm{L}$ Poly(dI-dC), $0.05 \% \mathrm{NP}-40$ and $20 \mathrm{fmol}$ of biotin-labeled probe, in a final volume of $20 \mu \mathrm{L}$. 4 pmol of unlabeled (-892/-451) promoter DNA were added to the binding reaction mixture for competition studies. For supershift analysis, $1 \mu \mathrm{g}$ of anti-KLF15 mAb (AbCam, Cambridge, UK) was pre-incubated with nuclear extract for $1 \mathrm{~h}$ at $4{ }^{\circ} \mathrm{C}$ prior to the binding reaction. Reaction products were separated by electrophoresis in a $4 \%$ polyacrylamide gel (29:1, acrylamide/ $\mathrm{N}$, $\mathrm{N}^{\prime}$-methylene bisacrylmamide) in $0.5 \times \mathrm{TBE}$. The protein-DNA complexes were then transferred onto a positively charged nylon membrane (Hybond-N+, Amersham Pharmacia Biotech, Uppsala, Sweden) and detected by chemiluminescence.

\section{Results}

\section{Isolation and characterization of the rat $\alpha 1,6$} fucosyltransferase cDNA

In order to clone the rat fut $8 \mathrm{cDNA}$, the putative rat mRNA sequence of 1728 pb (NM_001002289.1) provided by the NCBI genome annotation division http:// www.ncbi.nlm.nih.gov/sites/entrez was used as a probe for BLAST analysis of rat genomic and EST divisions of NCBI databases. The coding sequence of rat $\alpha 1,6$ fucosyltransferase was localized on chromosome 6 , divided into nine exons and spanning over $140 \mathrm{~kb}$ (Figure 1A). Homologous EST sequences obtained were conceptually translated and partially overlapping sequences were assembled to build a larger open reading frame (ORF) (Figure 1B). Three ESTs CB548120.1, CB 730213.1 and CB730572.1 correspond to the 5'-region of the fut8 gene, and the sequences FM069692.1, DV727207.1 and CB742993.1 correspond to the 3'-region. These sequences were used to generate oligonucleotide primers located in the 5'- and 3'-untranslated regions for PCR cloning. A unique $1942 \mathrm{pb}$ PCR fragment was amplified from YB2/0 cells cDNA library, cloned into the pCR IIBlunt TOPO vector and entirely sequenced.

The amplified sequence contains an ORF of $1725 \mathrm{bp}$, showing 4 nucleotide changes (at $+340(\mathrm{a} / \mathrm{c}),+418(\mathrm{t} / \mathrm{c})$, $+891(\mathrm{t} / \mathrm{c})$ and $1313(\mathrm{c} / \mathrm{t})$ from ATG) compared to the putative rat fut8 ORF sequence (NM_001002289.1), which were also found, at least for two of them, in EST sequences of the NCBI databases (125463675/ 102469807, 1660740078/8735204) and reflect a silent allelic polymorphism in rat fut8 gene without change in the amino-acid sequence of the polypeptide. The nucleotide and deduced amino acid sequences of the full-length cDNA obtained are shown in Figure 2. The position of the initiation codon was estimated according to the Kozak consensus sequence [31]. Hydropathy analysis of the polypeptide indicated the presence of a hydrophobic sequence of 19 amino acids in the $\mathrm{NH}_{2}$ terminal region, corresponding to the transmembrane domain characteristic of type II Golgi glycosyltransferases. The predicted protein consisted of 575 amino acids, containing the three specific motifs of $\alpha 1,6$ fucosyltranferase in the catalytic domain (Figure 2). Comparison of the amino acid sequence with those of the human and pig orthologs, shows $94 \%$ and $88 \%$ identity, respectively.

In order to conclusively confirm that the YB2/0 cloned fut 8 cDNA encodes an active $\alpha 1,6$-fucosyltransferase, the cDNA was inserted in pcDNA3.1 expression vector. The construction was transiently transfected into COS-7 cells. $72 \mathrm{~h}$ after transfection, the $\alpha 1,6$-fucosyltransferase activity was measured in cell extracts using asialo-agalacto apotransferrin as acceptor substrate for in vitro assays. The $\alpha 1,6$-fucosyltransferase activity was 4 times higher $(2135+/-318 \mathrm{cpm})$ in pcDNA-Fut8 transfected COS-7 cell extracts than in the control cells $(500+/-200 \mathrm{cpm})$, confirming that the cloned cDNA encodes an active enzyme.

\section{Fluorescence In Situ Hybridization}

Copy number of fut8 gene was counted on at least 50 interphase nuclei of YB2/0 cell line and appropriated controls. Results are summarized as percentage and mean copy number in Table 4 and representative pictures of the different samples are shown in Figure 3. It appears that the rat myeloma cell line YB2/0 has a mean copy number of fut 8 gene of $2.8 \pm 1.4$ whereas the rat primary lymphocyte has only $2.3 \pm 0.8$ of the same gene and the negative control with the NRP shows no hybridization. These differences are statistically significant with $\mathrm{p}<0.05$.

\section{Identification of rat fut8 transcription start sites}

To determine the transcriptional start sites (TSS) of rat fut8 gene, the mRNA 5'-ends were amplified by RLMRACE. To ascertain to only amplify full-length transcripts, we first selected full-length capped mRNA from total RNA extracted from YB2/0 cells. For that purpose, total RNA was first treated with calf intestine alkaline phosphatase for total dephosphorylation of uncapped RNAs, thereafter the full-length mRNA was uncapped with tobacco acid pyrophosphatase. The geneRacer RNA oligonucleotide was then ligated to the 5'-phosphate of the uncapped mRNA using T4 RNA ligase. Reverse transcription was performed with the GeneRacer oligodT primer, followed by a first PCR using the forward GeneRacer5'Primer provided and the reverse gene-specific primer 3F8Race3 located at the 5'-end of exon E2. Nested PCR was performed with the forward GeneRacer5'Primer Nested provided and the reverse gene-specific primer 3F8Race4 located into the first coding exon E1. As shown in Figure 4A, which is representative of at least three independent amplifications, four bands from 


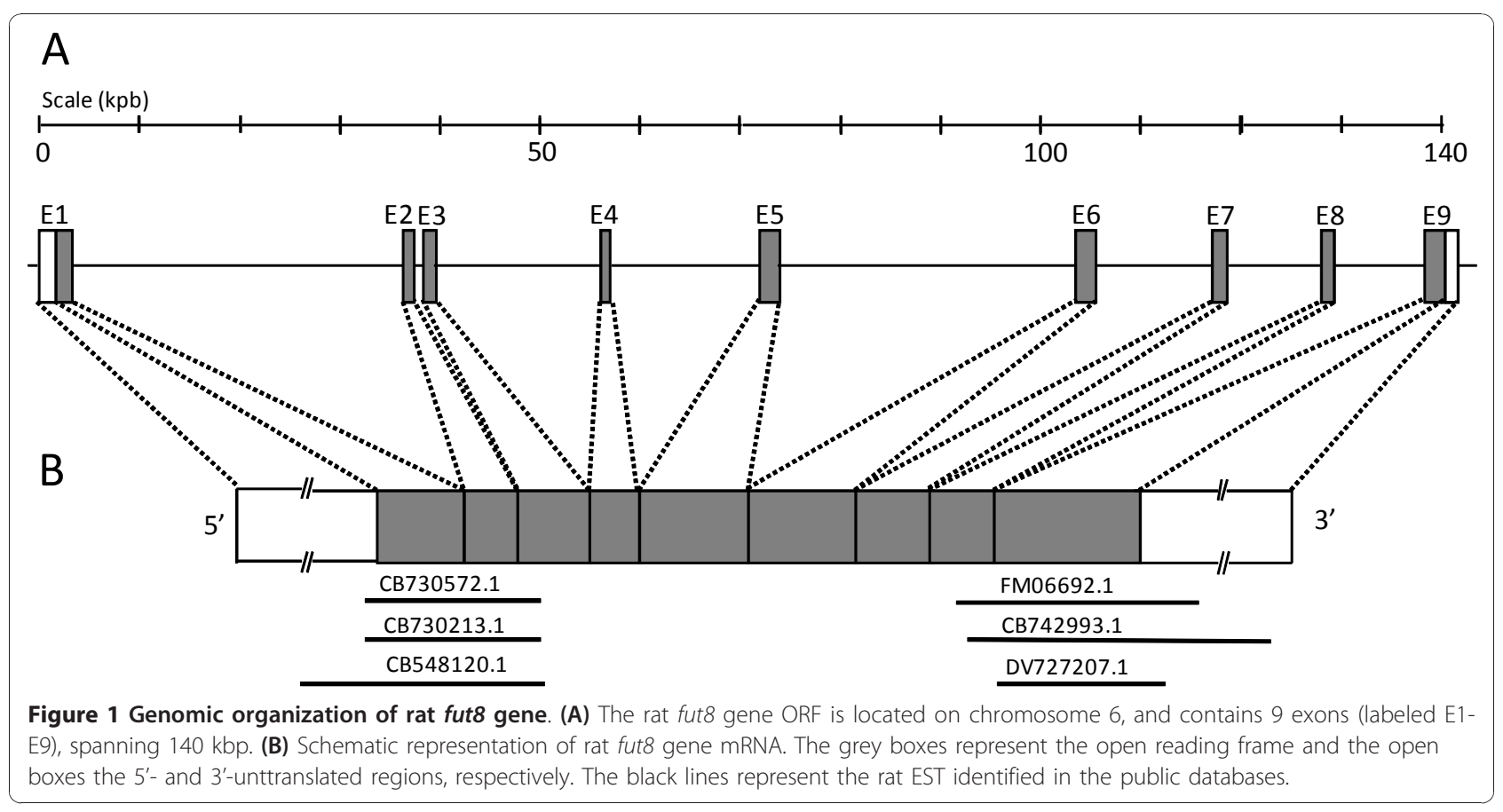

250 to $750 \mathrm{bp}$ were obtained. The PCR products were subcloned, sequenced and BLAST-aligned http://www. ncbi.nlm.nih.gov/BLAST/ against the rat genome. As expected, the amplified products were assigned to rat fut8 transcripts (NW_047761.1, NW_047771.1) excepted for the $450 \mathrm{bp}$ band, which was not specific. Three different 5 '-ends of fut $8 \mathrm{mRNA}$ were identified, testifying the existence of three transcript isoforms. The T1 transcript [EMBL: FN668936] corresponding to the $600 \mathrm{bp}$ amplified fragment, is extended by $508 \mathrm{bp}$ from the ATG and composed of 4 exons named E-2, E-1, E0 and E1 as shown in Figure 4B. Twenty different clones from three independent RLM-RACE were sequenced, defining 3 TSS for T1, at $-508,-500$ and -447 bp from the ATG (Figure 4B). The T2 transcript [EMBL: FN668937], corresponding to the $750 \mathrm{bp}$ amplified product, is extended by about $537 \mathrm{bp}$ and composed, as well, of the exons E-1, E0 and E1 but the exon E-2 is substituted by exon E-3. The sequencing of 28 clones allowed the identification of six TSS at position $-537,-505,-498,-496,-473$ and -469 bp from the ATG (Figure 4B). Finally, the T3 transcript [EMBL: FN668938] was the smallest one and corresponded to the $250 \mathrm{bp}$ product. The T3 transcript 5 -untranslated region was only composed of the 3 '-end of exon E1, with 5 TSS at position -222, -216, -171, -129 and -46 from the ATG (Figure 4B). A schematic representation of the 5'-untranslated region of fut 8 gene and of the three transcript isoforms identified by RLMRACEis shown in Figure 5. Similar results were obtained for Rat 2 cells and rat liver RNA preparations, excepted for T3 transcript, the presence of which was not confirmed in both cases.

\section{Quantification of transcripts in cultured cells by duplex Taqman $^{\text {TM }}$ QPCR}

The relative expression of fut8 specific transcripts was determined by duplex Taqman ${ }^{\mathrm{Tm}}$ QPCR using HPRT as a normalizing gene. For T1 transcript, a forward primer hybridizing within E-2 and a reverse primer that hybridizes within the exon E-1/E-2 junction of fut 8 cDNA sequence were designed (Table 1). For the T2 transcript, the primers pair was designed hybridizing within E-3 sequence for the forward primer and in the exon E-1 for the reverse primer. Taqman ${ }^{\mathrm{TM}}$ probes were designed within exon E-1 and E-3, respectively. For HPRT, primers and probe were designed to hybridize within exon $7 /$ exon 8 sequences of the coding region (Table 1 ). The relative expression of specific transcripts was determined for YB2/0 and Rat2 cell lines. As shown in Figure 6, the expression of T2 transcript was 1.6-fold higher than the expression of $\mathrm{T} 1$. This pattern of expression was similar in both cell lines (Figure 6).

The direct quantification of T3 transcript expression was not possible because the totality of the 5'-UTR sequence is common to the sequences of the T1 and T2 transcripts. Moreover, the quantification of the total transcripts of fut8 using primers designed in E-1 and E0 exons didn't allow determining the expression level of T3. Nevertheless, the T3 transcript appeared to be weakly expressed in both cell lines compared to T1 and T2. 


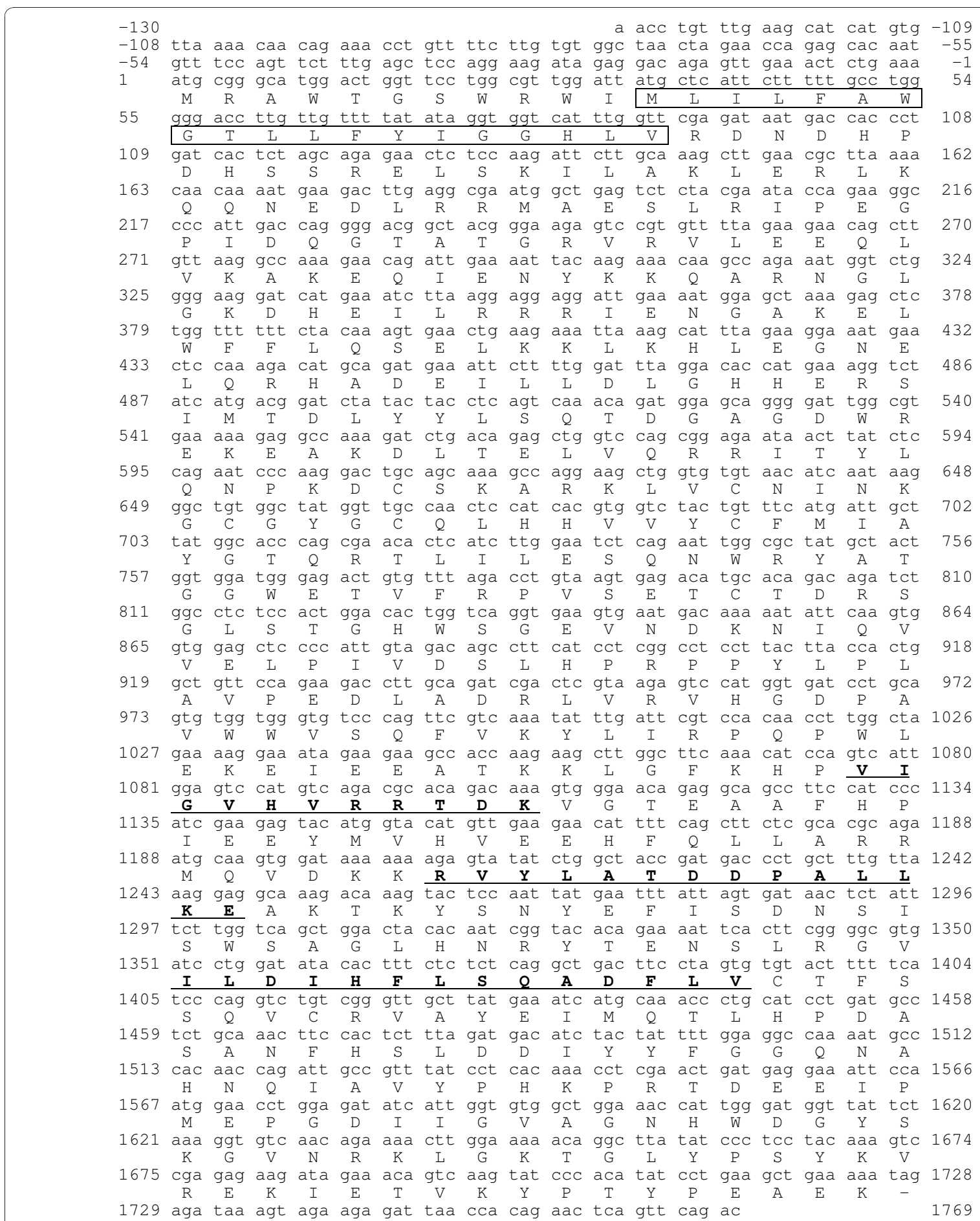

Figure 2 Rat fut8 cDNA sequence. Numbering of the CDNA begins with the initiation codon. The amino acid sequence is shown in singleletter code. The putative 19 amino acid N-terminal transmembrane domain is boxed. The three $\alpha 1,6$-fucosyltransferase specific motifs (motifs I, II \& III) are underlined. The open boxes mark the position of differences with the provisional sequence.

Promoter activity of the $5^{\prime}$-upstream region of $\mathrm{T} 1$ and $\mathrm{T} 2$ To determine the minimal promoter region of the $\mathrm{T} 1$ transcript, the $1 \mathrm{~kb}$ genomic sequence between E-3 and E-2 was subcloned in the pGL3b upstream the luciferase gene and named pGL3(-1438/-411). This plasmid and the 5'- or 3'-deleted constructions pGL3(-1438/-598), pGL3(-1438/-451), pGL3(-598/-411), pGL3(-892/-411), pGL3(-892/-451), pGL3(-892/-598), pGL3(-1004/-411) and pGL3(-1205/-411), were transfected into YB2/0 and Rat2 cells for luciferase assays. Unfortunately, the 
Table 4 Number of copies of fut8 gene in YB2/0 interphase nuclei

\begin{tabular}{|c|c|c|c|c|c|c|c|c|}
\hline \multirow[b]{2}{*}{ Sample } & \multirow[b]{2}{*}{ Type } & \multirow[b]{2}{*}{ Probe } & \multicolumn{5}{|c|}{$\begin{array}{l}\text { Number of copies } \\
\text { (\% of cells) }\end{array}$} & \multirow[b]{2}{*}{$\begin{array}{l}\text { Mean } \pm \\
\text { SD }\end{array}$} \\
\hline & & & 0 & 1 & 2 & 3 & $\begin{array}{l}4 \text { or } \\
\text { more }\end{array}$ & \\
\hline YB2/0 & Sample & $\begin{array}{l}\text { Rat } \\
\text { fut8 }\end{array}$ & 6.5 & $N D^{b}$ & 8 & 60 & 25.5 & $2.8 \pm 1.4$ \\
\hline$P R L^{a}$ & $\begin{array}{l}\text { Positive } \\
\text { control }\end{array}$ & $\begin{array}{l}\text { Rat } \\
\text { fut8 }\end{array}$ & ND & 10 & 64 & 13 & 13 & $2.3 \pm 0.8$ \\
\hline YB2/0 & $\begin{array}{l}\text { Negative } \\
\text { control }\end{array}$ & $\mathrm{NRP}^{\mathrm{C}}$ & 100 & ND & ND & ND & ND & \\
\hline
\end{tabular}

The number of copies of fut8 gene observed by FISH is expressed as a percentage of cells.

${ }^{a}$ : primary rat lymphocyte.

b: not detected.

c: non relevant probe.

luminescence intensity measured in YB2/0 for these different constructions was too weak to allow determining the promoter activity of this region in this cell line. The results obtained for Rat2 are presented in Figure 7, and show a 13-fold increase of luciferase activity for the full length plasmid pGL3(-1438/-411) compared to pGL3b, whereas the luciferase activity for pGL3(-1205/-411) and pGL3(-1438/-451) constructs shows a 38- and 30-fold increased activity, respectively. In parallel, luciferase activity for the pGL3(-892/-598) and pGL3(-598/-411) plasmids show only a 3- and 4-fold increased activity compared to pGL3b. These data suggest the existence of a minimal promoter region [EMBL: FN668939] (named P1) within the sequence $-892 /-451$, including positive and negative regulation regions in -892/-598 and 598/451 , respectively. In addition, the $-1205 /-1004$ and $-451 /-411$ sequences include positive regulation regions, whereas -1104/-892 sequence includes negative regulation regions.

We also analyzed the $1 \mathrm{~kb}$ region located upstream the E-3 exon with or without E-3 sequence to determine the minimal promoter region controlling the transcription of $\mathrm{T} 2$ transcript. The full length region with the
E-3 region was PCR amplified and subcloned in the pGL3b upstream the luciferase gene and named pGL3 $(-1399 /-404)$. This plasmid, or 5'- or 3'-deleted constructions were transiently transfected in Rat 2 cells. All the constructions increase the luciferase activity compared to pGL3b. The results presented in Figure 8 show a 7- to 11-fold increase of luciferase activity for the constructions without the E-3 exon, whereas the luciferase activity for constructs with E-3 exon shows a 28- and 36 -fold increased activity. No significant differences in luciferase activity were observed between the pGL3 (-1399/-537), pGL3(-998/-537) and pGL3(-720/-537) constructions. These results suggest the existence of a minimal promoter region [EMBL: FN668940] (named P2) within the sequence $-720 /-537$ upstream the ATG and a positive regulation region in the exon E-3.

\section{Bioinformatics analysis of P1 and P2 minimal promoter regions}

The putative minimal promoter regions upstream exons E-2 and E-3 were analyzed with Matinspector $2.2 \mathrm{http}: / /$ www.genomatix.de using TRANSAC matrices 4.0 [29]. Lymphoid and myeloid cell-specific filters were applied to sort the identified transcription factors consensus sequences and core similarity was fixed at $95 \%$. A particular attention was put on consensus sequences for transcription factors with repressor activity, potentially usable for the control of fucosylation in YB2/0. Results of these bioinformatics analysis are shown in Figure 9. In both cases, the analyses did not reveal any canonical TATA or CAAT boxes, but several putative binding sites for general transcription factors and for transcription factors with repressor activity. For the P1 minimal promoter region (-892/-451) controlling the transcription of T1 transcript, consensus sequences for the putative repressors MZF1 (Myeloid Zinc Finger 1), PAX5 (Paired Box 5), KLF15 (Krüppel-like Factor 15), IRF3 (Interferon Regulatory Factor 3) and PRDM1 (Positive Regulatory Domain containing 1) were identified (Figure 9). For the P2 minimal promoter region, we
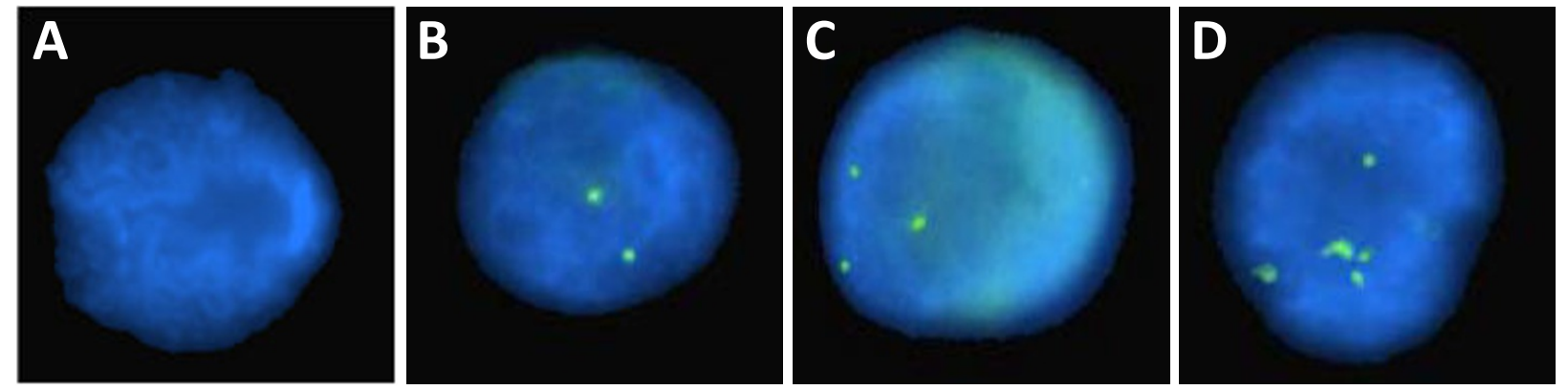

Figure 3 Fut8 copy number in interphase nuclei of YB2/0. Picture A shows nucleus hybridized with a non relevant probe. Pictures B, C and D show YB2/0 nuclei with 2, 3 and 5 copies of fut8, respectively. 


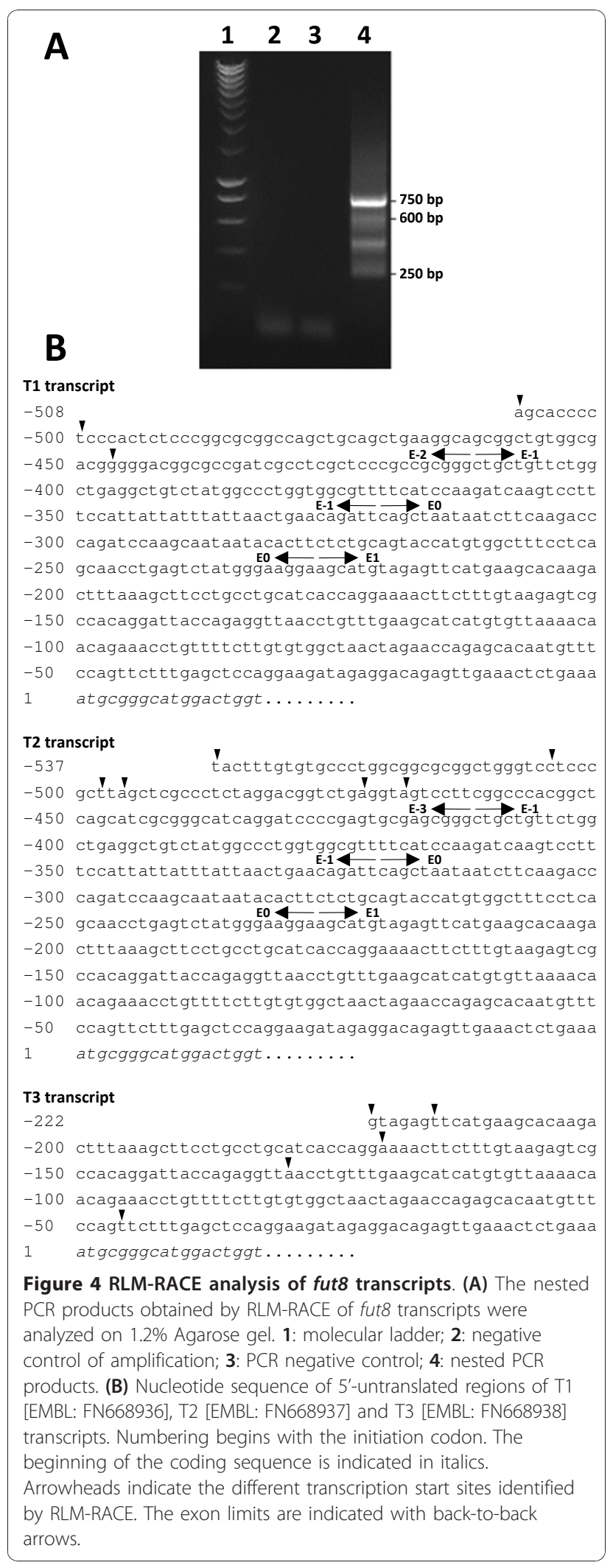

identified potential repressor binding sites for HELT (Hey like transcriptional repressor), CDP (CCAAT displacement protein), MEL1 (MDS1/EVI1-like gene 1), NKX3.1 (androgen-regulated homeobox protein), IKRS (Ikaros) and the zinc-finger transcription factor Gfi-1.

\section{Effect of KLF15 over-expression on the P1 minimal promoter activity}

In order to determine the effect of the potential repressor transcription factors on minimal promoter P1 activity, we co-transfected Rat2 cells with MZF1, PAX5, KLF15, IRF3 or PRDM1 expression vectors and with reporter vector pGL3(-892/-451) containing the minimal promoter P1 sequence. 48 hours after transfection, luciferase assays were performed and showed that only KLF15 was able to reduce the minimal promoter activity of T1 transcript by about $50 \%$, at each concentration of vector tested (Figure 10B and additional file 1). These results were statistically significant $(P<0.0005)$ and suggested that KLF15 had repressor activity. A similar repressor effect of KLF15 was observed on the on pGL3 $(-1438 /-451)$ construct (data not shown). The overexpression of KLF15 protein was checked by Western Blot in nucleus and cytoplasm fractions of Rat2 cells. As shown in Figure 10A, the anti-KLF15 mAb revealed two bands at about $55 \mathrm{kDa}$, in agreement with the apparent molecular weight of KLF15 protein in SDS-PAGE [32]. Endogenous KLF15 was mainly present in the cytosolic fraction (see mock cells) and the amount of KLF15 protein increased in both in nucleus and cytoplasm fractions with the concentration of transfected vector in a dose-dependent manner. At the lowest concentration of vector, KLF15 is mainly over-expressed in the nucleus fraction and the repression of luciferase activity for higher concentrations of vector doesn't change in spite of the increase of the protein in both fractions. These data indicate that the smallest quantity of KLF15 that accumulates in the nucleus is sufficient to observe a maximal repressor effect.

\section{Binding of nuclear proteins to P1 minimal promoter sequence}

To investigate the association between nuclear proteins and the (-892/-451) P1 minimal promoter sequence, EMSA assay was performed to determine whether Rat2 cells nuclear proteins could bind this sequence. As shown in Figure 10C, a strong band was shifted (open arrow) when the nuclear extract was incubated with the biotinylated DNA fragment. The shifted band was significantly inhibited by a molar excess of unlabeled competitor. In order to further determine if KLF15 binds to 


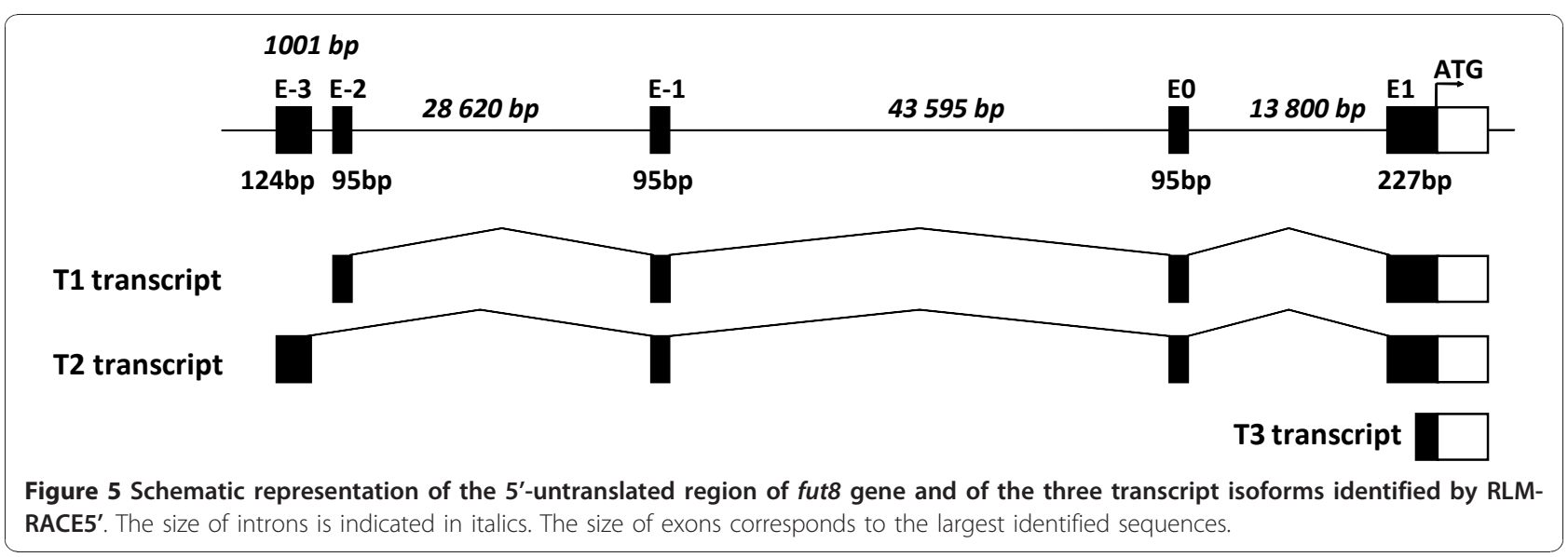

the promoter sequence, super-shift assay was performed using anti-KLF15 mAb but no supplementary band was detected. This result indicates that KLF15 may not directly interact with the minimal promoter sequence.

\section{Discussion}

The rat hybridoma cell line YB2/0 is considered as an alternative for the large-scale production of low fucose IgG [9]. The fucose transfer capacity of YB2/0 is much lower than the other rodent cell lines commonly used [27]. However, the amount of fucose-negative antibody produced by YB2/0 significantly decreased with the culture, due to the elevation of fut 8 expression by the YB2/ 0 cells [27]. Important variations of the fucose content are also observed in production culture conditions.

To improve our knowledge of YB2/0 fucosylation machinery, we have cloned rat fut8 cDNA. Fut8 gene coding region spans over $140 \mathrm{~kb}$ of rat chromosome 6 and splits into nine coding exons with an organization closely related to that of the human ortholog [33]. The rat fut8 cDNA contains an ORF of $1725 \mathrm{bp}$, encoding a 575 amino acids polypeptide, showing $94 \%$ and $88 \%$ identity with the human and porcine enzymes, respectively. The amino acids sequence contains the three specific motifs of $\alpha 1,6$-fucosyltranferase in the catalytic domain (Figure 2). These motifs are shared by $\alpha 2$-fucosyltransferases, $\alpha 6$-fucosyltransferases, and proteinO-fucosyltransferases (POFUT), indicating that the corresponding genes have originated from a common ancestor by duplication and divergent evolution [34].

Interestingly, we identified 4 nucleotide changes in the coding sequence of rat fut 8 cDNA when compared to the putative sequence (NM_001002289.1). Two of these SNP were also found in different EST sequences of the

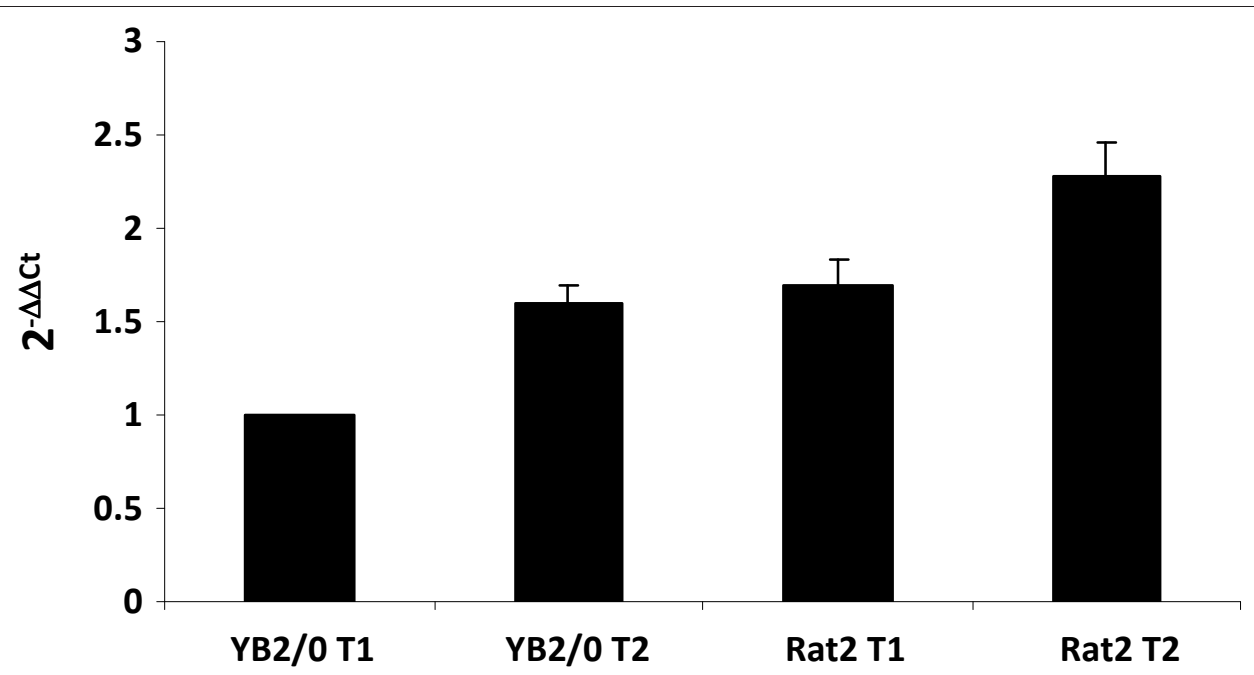

Figure 6 Quantification of T1 and T2 transcripts expression in YB2/0 and Rat2 cells by duplex Taqman ${ }^{\mathrm{TM}}$ QPCR. Results were normalized to the expression of HPRT mRNA and expressed relative to T1 mRNA expression level in YB2/0. The quantification was performed by the method described by Livak and Schmittgen [53]. 

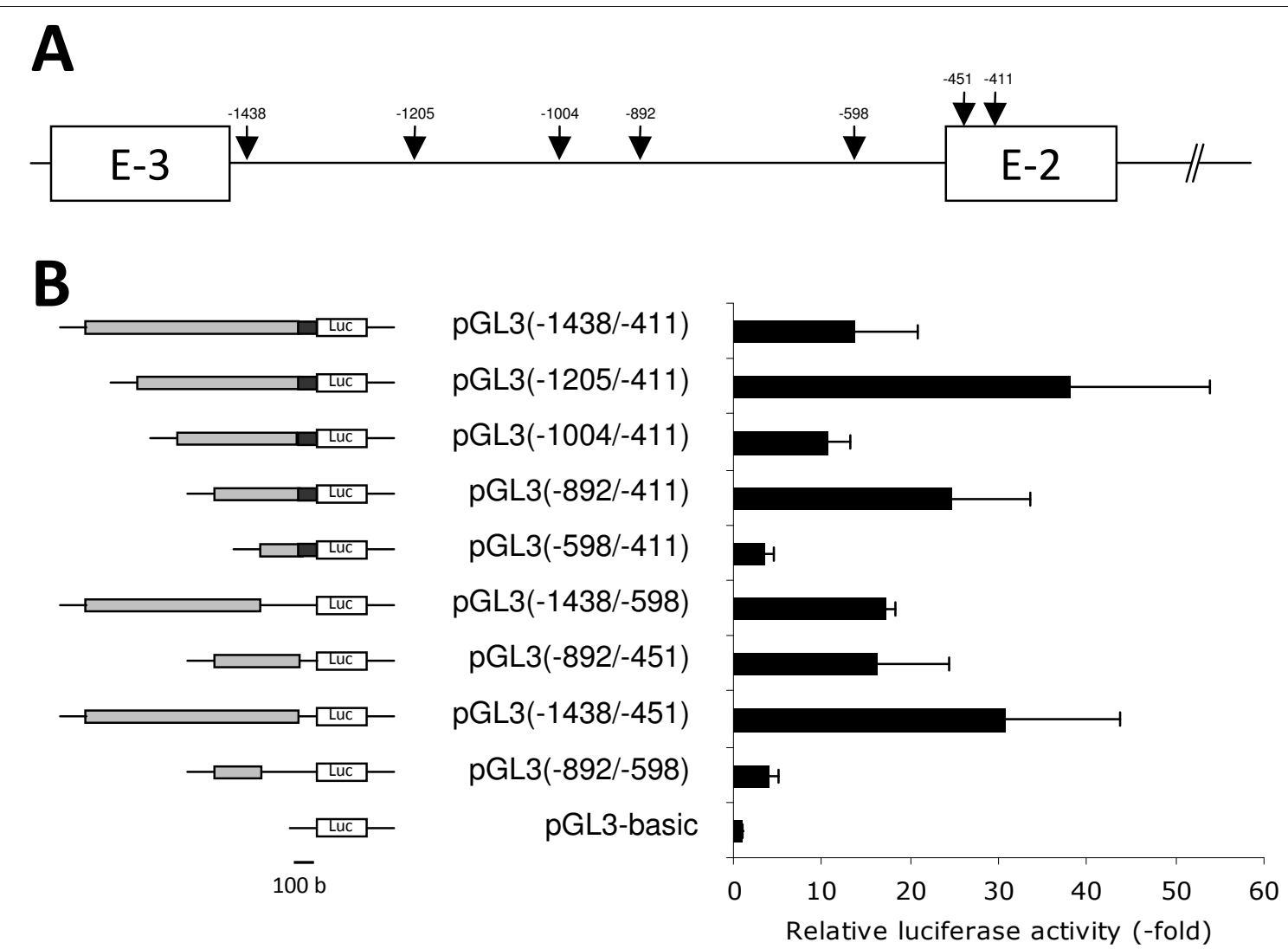

Figure 7 Luciferase assays after transfections in Rat2 cells of different plasmid constructs for T1 transcription analysis. (A) Location on the genomic sequence of the restriction sites used to generate the different deletions of the intronic region between exons E-2 and E-3. Numbering begins with the initiation codon. (B) On the left, a schematic representation of the different constructs inserted in pGL3b upstream of the luciferase gene. The gray boxes represent the different deletions of the $1 \mathrm{kbp}$ intronic region between exons E-2 and E-3. The black box indicates the 5'-end of E-2. Luc indicates the Firefly luciferase coding sequence and the lines indicate the missing sequences. On the right: the results of luciferase assays. Transfection efficiencies were normalized with the co-transfected plasmid expressing Renilla luciferase and luciferase activities are expressed compared to pGL3b activity. The data are means +/- S.D. of $n>=3$ experiments.

NCBI databases, showing the existence of a silent allelic polymorphism in rat gene, but without change in the amino-acid sequence of the polypeptide.

By FISH, we were able to determine the copy number of fut8 gene in YB2/0, showing a heterogeneous cell population, $60 \%$ of cells having three fut 8 copies and $25.5 \%$ with 4 or more copies, the mean copy number being $2.8 \pm 1.4$ (Figure 3). Hybridoma cell lines such as YB2/0 are usually tetraploid but are also genetically instable. Depending on the culture medium, continuous cultivation induces chromosome rearrangements and loss of genetic material [35] that can explain fut8 heterogeneity. Even if other parameters dependent on the culture conditions may also influence fut 8 expression during the cultivation, the heterogeneity of fut 8 copy number should also have important consequences in fucosylation capacity of these cells.

RLM-RACE experiments with capped RNAs allowed to define for the first time the organization of the 5'-untranslated region of rat fut8 gene and to identify the different TSS. The rat fut8 gene 5'-untranslated region contains 4 exons spanning about $90 \mathrm{~kb}$. Three mRNA isoforms were identified, arising from alternative splicing and alternative promoter usage, as shown in Figure 5. The quantification of $\mathrm{T} 1$ and $\mathrm{T} 2$ transcripts relative expression was performed by duplex Taqman ${ }^{\mathrm{Tm}}$ QPCR, showing that T2 transcript was 1.6-fold higher expressed than the T1. This pattern of expression was similar in both YB2/0 and Rat2 cell lines. Several TSS were identified for each transcript, which is a common attribute for TATA-less promoter [36]. Data concerning fut8 5'-untranslated region and transcripts expression are rather limited. It has been shown that in the human SK-OV-3 ovarian cancer cells, FUT8 expression is controlled by the 5 -flanking region upstream exon 1 . However, other 5'-untranslated sequences were found in ESTs, suggesting the presence of additional exons upstream exon 1, and that the transcription of the gene 


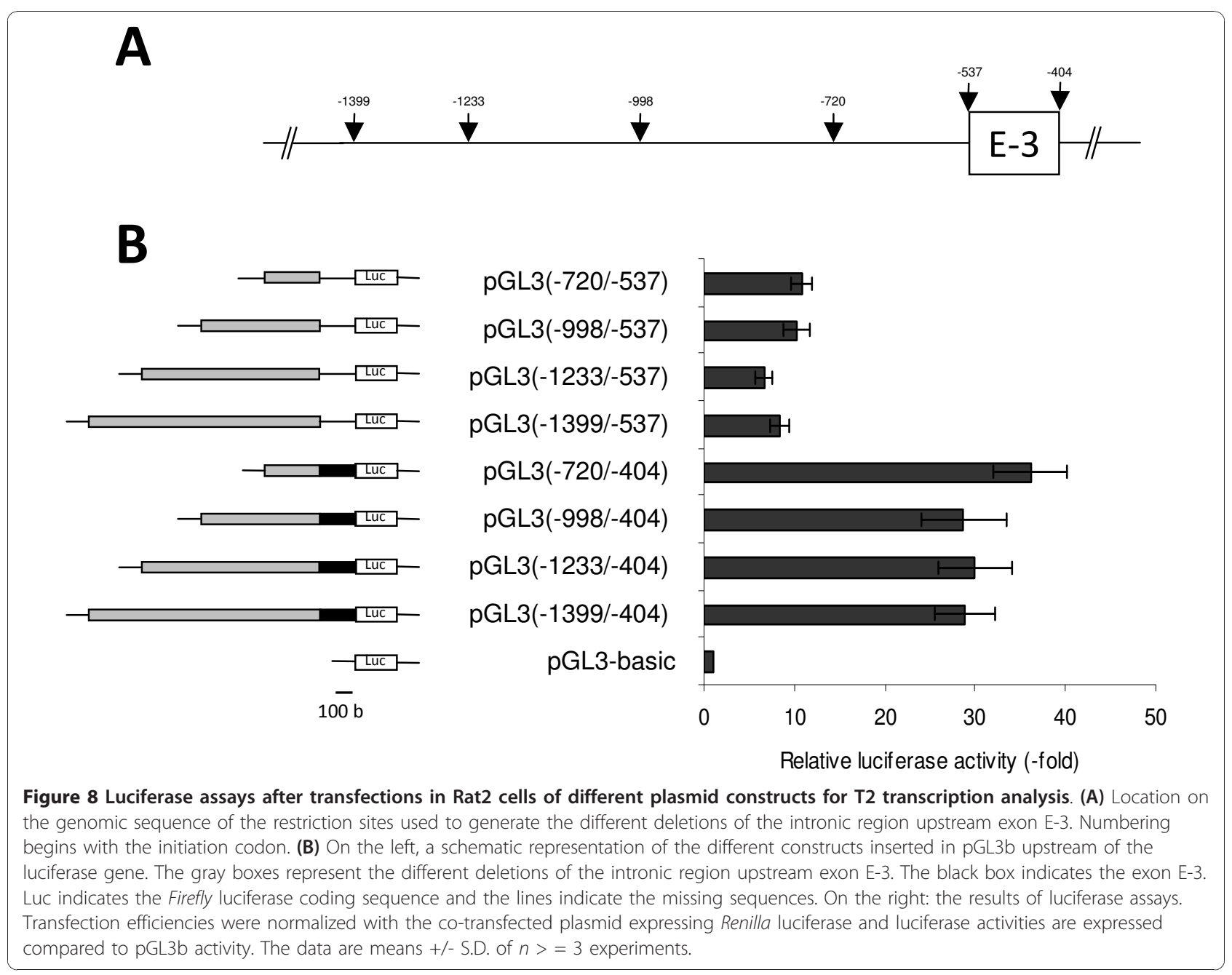

would be regulated by multiple promoters [37]. Two additional 5'-untranslated exons were identified upstream human FUT8 exon 1, which are expressed during embryogenesis as three groups of transcripts, suggesting an expression of FUT8 regulated by three different promoters [33]. From these data, it appears that rat and human FUT8 genes have a quite similar organization and pattern of expression, with at least three different transcripts encoding the same polypeptide.

The alternative first exons E-2 and E-3 are located about $90 \mathrm{kbp}$ from the first coding exon $\mathrm{E} 1$ and separated by a $1 \mathrm{kbp}$ intronic sequence. The $1 \mathrm{kbp}$ rat genomic sequences upstream exons E- 2 and E-3 were cloned in the pGL3b upstream the luciferase gene to determine the minimal promoter regions controlling the transcription of T1 and T2. These plasmids and 5'- or 3'-deleted constructions were transfected into YB2/0 and Rat2 cells for luciferase assays. However, the ratio of luminescence intensity for these different constructions compared to the control pGL3b was too low to allow determining the promoter activity in YB2/0. Nevertheless, we were able to delimitate the minimal promoter regions controlling the expression of both transcripts in Rat 2 cells. We could show that the T1 transcript is controlled by a minimal promoter region within the sequence $-892 /-451$ from ATG with two negative regulation regions within the $-451 /-411$ and $-1438 /-1205$ sequences. The binding of Rat2 cells nuclear proteins to the P1 minimal promoter region was confirmed by EMSA analysis. We also showed the existence of a minimal promoter region within the sequence -720/-537 upstream the ATG for transcript T2 and a strong positive regulation region in the exon E-3. Few are known about the promoters of fut 8 in other species. Only one study has shown that in human ovarian cancer cells SK-OV-3, luciferase reporter assay indicated that the $1 \mathrm{kbp} 5$ '-flanking region of exon E1 conferred the promoter activity. This region contains a TATA-box, but not a CCAAT motif, and potential binding sites for some transcription factors, such as bHLH, cMyb and GATA-1 [37]. 


\section{A P1 minimal promoter sequence \\ -361 getagcgccggeccgaggettccecgcctgcgetccgggtcggagccactcaggcgcgtg - MZF1 - PAX5 \\ -301 cgcgcgtggtctcgggecgacccgagtggecgggttctctgagetccaggcccccgecgc \\ -241 cccctcccggetcccagccaacccgtcettccetttcctcacggaatgggtccggegetg - $\overline{\text { KLF15 }}$ - NFAT/IRF7/PU1 \\ -181 ctcggggtcgcgcgcectggacccggctcgcgctcggtctcgegctgtcagccgctgcct - VMAF \\ -121 ggetcgegecgcettgcgctttccetcagtcagtggcgcegaaggetccgttaagcggeg - IRF3/PRDM1 - VMYB + AREB6 + AREB6 \\ -61 gecgeggttcetgtttcegtttctectctccettcagtegggagtagcatcctccaccC - SPIB / IRF3 / NFAT / ELK1 $\frac{\text { - OLF1 }}{- \text { EVI1 }}-\overline{\text { KLF15 }}$

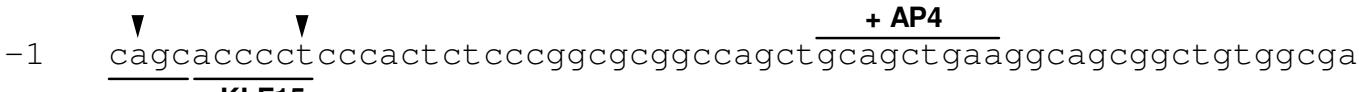 - KLF15 \\ 60 cgggggacggcgccgatcg \\ - PAX5}

B P2 minimal promoter sequence

$-183 \mathrm{ctt}$

- MYB $\underline{- \text { NKXH }}$ - Activator

-181 gagggcagctttctactcagccacccgtttgagtcctcaggttttgggatctggatccc

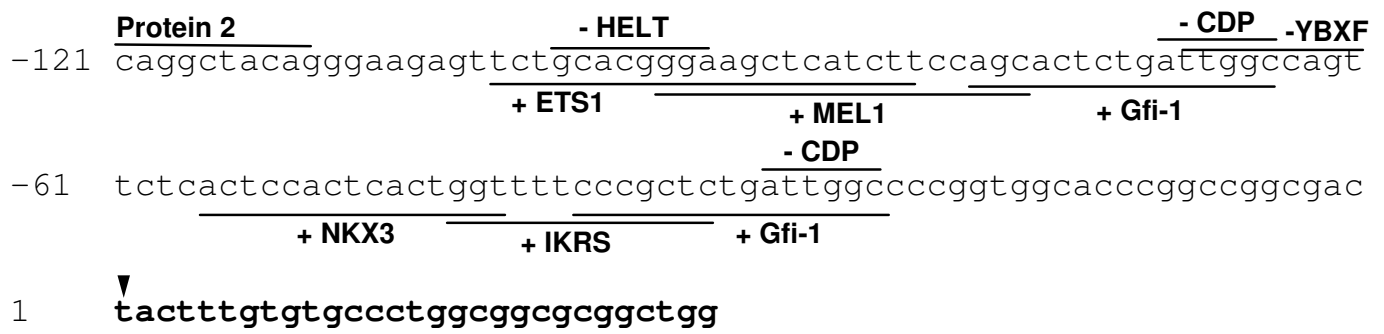

Figure 9 In silico analysis of the minimal promoter regions of T1 and T2 transcripts. (A) The 439 bp sequence [EMBL: FN668939] upstream the TSS (arrowheads) of the shortest T1 transcript were analyzed with Matinspector 2.2 software. Potential transcription factor binding sites are underlined with black lanes, below the sequence when the binding site is on the -strand and above when the binding site is on the + strand. Nucleotides are numbered with the nucleotide +1 as the first TSS. (B) The 183 bp sequence [EMBL: FN668940] defined as the minimal promoter region upstream the $\mathrm{T} 2$ transcript was analyzed in the same way.

Bioinformatics analysis of the promoter regions did not reveal any canonical TATA or CAAT boxes, but several putative binding sites for general transcription factors. Absence of TATA or CAAT boxes is a common feature of glycosyltransferase genes [38]. It is also in agreement with the presence of several TSS for the three transcripts, which is usual for such promoter regions. We also identified in both minimal promoter sequences several binding sites for transcription factors with repressor activity, which could be interesting 


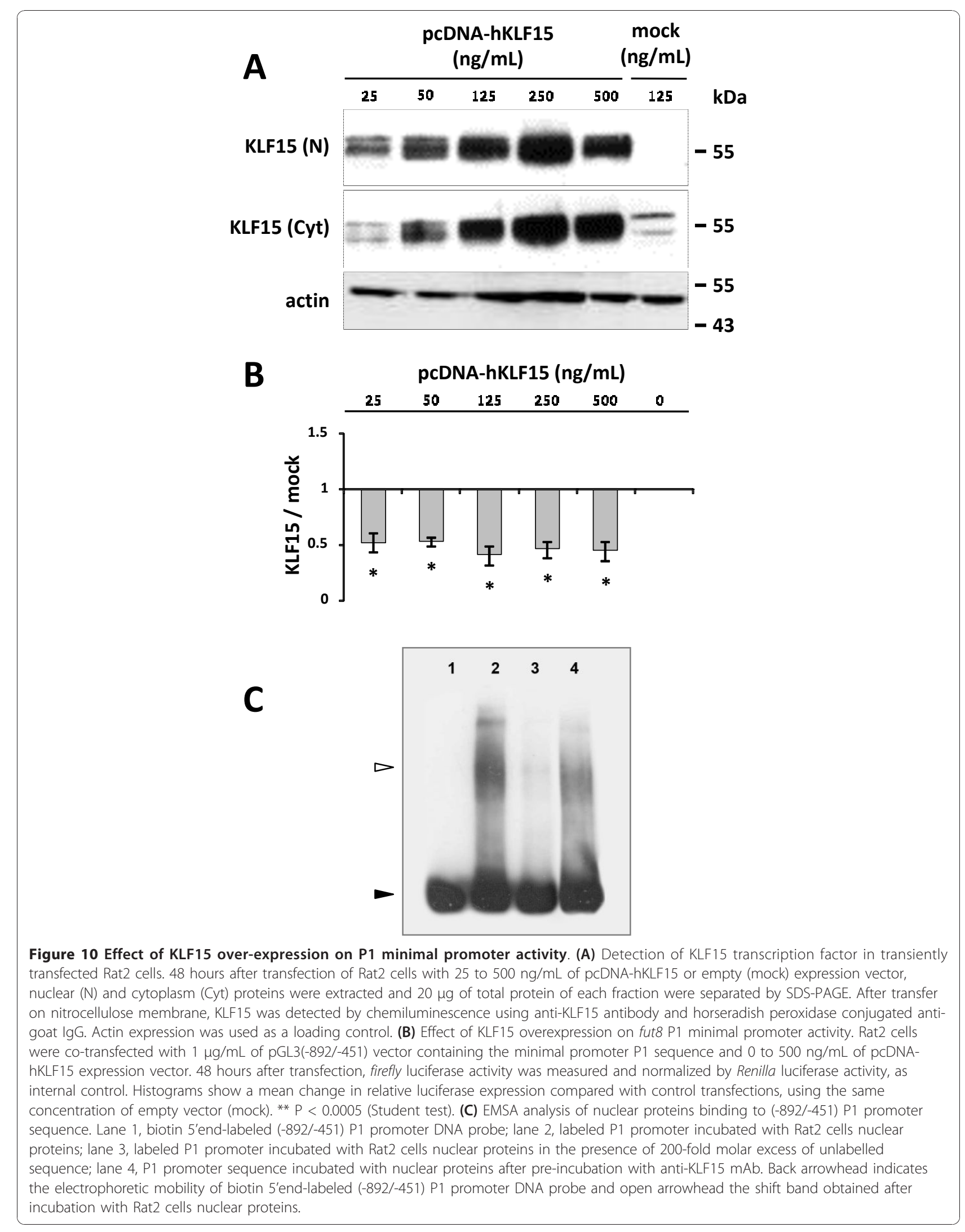


targets to regulate fut8 in YB2/0. MZF1 (Myeloid Zinc Finger 1), PAX5 (Paired Box 5), KLF15 (Krüppel-like Factor 15), IRF3 (Interferon Regulatory Factor 3) and PRDM1 (Positive Regulatory Domain containing 1) consensus sequences have been identified in P1 promoter. MZF1 is known to regulate transcription of genes involved in cell growth, differentiation and apoptosis of myeloid cells. It is described as a repressor in non-hematopoietic cells and activator in hematopoietic cells [39]. PAX5 is known to down-regulate genes implicated in myeloid or T-lymphocyte differentiation in pro- B lymphocytes [40]. Interestingly, it has been shown that fut 8 is up-regulated in PAX5-/- cells [40]. KLF15 has been demonstrated as a repressor of several important genes such the adrenomodullin gene in adipocytes [41] or the rhodopsin and the IRBP (Interphotoreceptor Retinoid Binding Protein) genes [42]. IRF3 is described as a repressor of RXR $\alpha$, which is a key partner for number of nuclear receptors [43]. PRDM1 (alias Blimp1 or Prd1Bf1) is known to repress several critical genes in B lymphocytes such as c-Myc [44]. HELT (Hey like transcriptional repressor), CDP (CCAAT displacement protein), MEL1 (MDS1/EVI1-like gene 1), Nkx3.1 (androgen-regulated homeobox protein), IKRS (Ikaros) and the zinc-finger transcription factor Gfi-1 were also identified in minimal promoter P2. HELT was shown to act as a transcriptional repressor in the neuronal development [45]. $\mathrm{CDP}$ is known to interact with regulatory element from a large number of genes involved in differentiation, cell growth and development. It is acting as a repressor by either a direct repressing effect when stably bound to the promoter, or by competing with activator factors for the occupancy of their binding sites [46]. MEL1 is described to have an essential function in the proliferation and maintenance of hematopoietic stem cells [47]. MEL1 is also known as a transcription repressor factor in the regulation of calreticulin expression, acting as a competitor with GATA6 factor [48]. Nkx3.1 is a homeodomain transcription factor, described as a transcriptional inhibitor of estrogen receptor activity, acting as a putative repressor in hormone-driven tumors [49]. IKRS factors are zinc finger DNA binding proteins. Six isoforms of IKAROS are described that often act as repressors. They seem to have a regulation role in the lymphocyte ontogeny [50]. Gfi-1 is described as a transcriptional repressor in lymphoid cell but its function can change with the cell context in hematopoietic development [51].

These transcriptional repressors can potentially bind to the fut 8 minimal promoter regions and, in a first approach to control fut 8 expression, the identified putative repressors of $\mathrm{T} 1$ transcript were co-transfected in Rat2 cells with reporter vector pGL3(-892/-451) containing the minimal promoter P1 sequence. No repressor activity was observed with MZF1, PAX5, IRF3 or
PRDM1. In particular, we were not able to confirm the repressor activity of PAX5, as previously demonstrated in Pax5-/- cells [40]. However, KLF15 expression induced a $50 \%$ decrease of luciferase activity, whatever the concentration of vector. Western blot analysis of transfected cell lysates using anti-KLF15 mAb revealed two bands around $55 \mathrm{kDa}$. Whereas the theoretical molecular weight of KLF15 is about $45 \mathrm{kDa}$, this is in agreement with the apparent molecular weight of KLF15 protein previously observed in SDS-PAGE [32]. The $8 \mathrm{kDa}$ difference between the two bands could be also explained by a post-translational modification such as SUMOylation, as it has been demonstrated for KLF5, another transcription factor of Krüppel Like Family [52]. Western blot showed that KLF15 is constitutively expressed in Rat2 cells, mainly in the cytosolic fraction, and increased in both nucleus and cytoplasm fractions with the concentration of transfected KLF15 expression vector in a dose-dependent manner. At the lowest concentration of vector, KLF15 is mainly over-expressed in the nucleus fraction. This is enough to observe a maximal repressor effect. This result indicates that a low expression of KLF15 in the nucleus results in a repression of the P1 minimal promoter activity.

\section{Conclusion}

The rat hybridoma cell line YB2/0 is potentially an alternative for the large-scale production of low fucose IgG because of lower fucose transfer capacity compared to the other rodent cell lines commonly used. However, nothing was known about the rat $\alpha 1,6$-fucosyltransferase. Our results shed light on the fut 8 gene organization and expression. Even if many other parameters such as GDP-Fuc concentration and transport or cell culture conditions can influence the fucosylation capacity of the cells, the heterogeneity of fut 8 copy number in YB2/0 could explain at least in part the variation of fucose content in IgG producing cell populations and impedes efficient gene knockdown strategy. Alternatively, the presence of potential repressor binding sequences in the minimal promoter regions of fut 8 could offer possible alternatives to control the fucosylation of IgG produced in these cells.

\section{Additional material}

Additional file 1: Effect of transcription factors over-expression on fut8 P1 minimal promoter activity. Bioinformatics analysis identified consensus binding sites for PRDM1, IRF3, PAX5, MZF1 and KLF15 putative repressors in the T1 transcript minimal promoter sequence. Human coding sequence of PRDM1, IRF3 and MZF1 were cloned into the pcDNA3.1 expression vector using the Gateway ${ }^{\mathbb{R}_{\circledast}}$ conversion system (Invitrogen, Carlsbad, CA, USA). The pcDNA3.1 vector containing the human KLF15 sequence was kindly provided by Dr. Otteson (College of Optometry, University of Houston, TX, USA) and the pcDNA3.1 vector containing the human sequence of PAX5 was provided by Dr. Broccardo 
(Centre de Physiopathologie INSERM U563, Toulouse, France). Rat2 cells were co-transfected with $1 \mathrm{\mu g} / \mathrm{mL}$ of pGL3(-892/-451) vector containing the minimal promoter P1 sequence and 0 to $750 \mathrm{ng} / \mathrm{mL}$ of PRDM1 (A), IRF3 (B), PAX5 (C), MZF1 (D) or KLF15 (E) expression vector. 48 hours after transfection, firefly luciferase activity was measured and normalized by Renilla luciferase activity, as internal control. Histograms show a mean change in relative luciferase expression compared with control transfections, using the same concentration of empty vector (mock). ${ }^{*} P<0.01,{ }^{*} P<0.0005$ (Student test).

\section{Abbreviations}

a1,6-FucT: the GDP-L-Fuc: N-acetyl- $\beta$-D-glucosaminide a1,6-fucosyltransferase; ADCC: Antibody-Dependent Cellular Cytotoxicity; CDP: CCAAT displacement protein; DMEM: Dulbecco's modified Eagle's medium; EMSA: electrophoretic mobility shift assays; EST: expressed sequence tags; FcyR: Fc fragment $\gamma^{-}$ receptor; FCS: fetal calf serum; FX: GDP-4-keto-6-deoxymannose 3,5epimerase, 4-reductase; GFT: GDP-fucose transporter; GMD: GDP-mannose 4,6-dehydratase; HELT: Hey like transcriptional repressor; Ig: immunoglobulin; IKRS: Ikaros; IRF3: Interferon Regulatory Factor 3; KLF15: Krüppel-like Factor 15; mAb: monoclonal antibody; MEL1: MDS1/EVI1-like gene 1; MZF1: Myeloid Zinc Finger 1; NKX3.1: androgen-regulated homeobox protein; NRP: non relevant probe; PAX5: Paired Box 5; pGL3b: pGL3-basic vector; PRDM1: Positive Regulatory Domain containing 1; QPCR: quantitative real-time polymerase chain reaction; RLM-RACE: RNA-Ligase-Mediated Rapid Amplification of CDNA Ends; TSS: transcription start site.

\section{Acknowledgements}

We would like to thank Dr. Deborah Otteson (College of Optometry, University of Houston, TX, USA) and Dr. Cyril Broccardo (Centre de Physiopathologie INSERM U563, Toulouse, France) for providing KLF15 and PAX5 expression vectors, respectively.

\section{Author details}

'Laboratoire Français du Fractionnement et des Biotechnologies, Lille, France. ${ }^{2}$ Univ. Lille Nord de France, F-59000 Lille, France. ${ }^{3}$ USTL, UGSF, F59650 Villeneuve d'Ascq, France. ${ }^{4}$ CNRS, UMR 8576, F-59650 Villeneuve d'Ascq, France.

\section{Authors' contributions}

BT carried out the molecular cloning, the enzyme activity characterization, transcripts' analysis and partially drafted the manuscript. EM carried out the P2 promoter characterization, MB carried out the P1 promoter characterization. AHL has performed the bioinformatic analysis. CG, AF \& SJ participated in the design and coordination of the study. AF performed FISH analysis and partially drafted the manuscript. PhD conceived of the study, participated in its design and coordination and drafted the manuscript. All authors read and approved the final manuscript.

Received: 24 February 2010 Accepted: 5 January 2011 Published: 5 January 2011

\section{References}

1. Nose M, Wigzell H: Biological significance of carbohydrate chains on monoclonal antibodies. Proc Natl Acad Sci USA 1983, 80:6632-6636.

2. Tao MH, Morrison SL: Studies of aglycosylated chimeric mouse-human $\mathrm{lgG}$. Role of carbohydrate in the structure and effector functions mediated by the human IgG constant region. J Immunol 1989, 143:2595-2601.

3. Jefferis R, Lund J, Pound JD: IgG-Fc-mediated effector functions: molecular definition of interaction sites for effector ligands and the role of glycosylation. Immunol Rev 1998, 163:59-76.

4. Mizuochi T, Taniguchi T, Shimizu A, Kobata A: Structural and numerical variations of the carbohydrate moiety of immunoglobulin G. J Immunol 1982, 129:2016-2020.

5. Krapp S, Mimura $Y$, Jefferis $R$, Huber $R$, Sondermann P: Structural analysis of human IgG-Fc glycoforms reveals a correlation between glycosylation and structural integrity. J Mol Biol 2003, 325:979-989.
6. Mattu TS, Pleass RJ, Willis AC, Kilian M, Wormald MR, Lellouch AC, Rudd PM, Woof JM, Dwek RA: The glycosylation and structure of human serum $\operatorname{lgA} 1$, Fab, and Fc regions and the role of N-glycosylation on Fc alpha receptor interactions. J Biol Chem 1998, 273:2260-2272.

7. Jefferis R: Glycosylation as a strategy to improve antibody-based therapeutics. Nat Rev Drug Discov 2009, 8:226-34.

8. Shields RL, Lai J, Keck R, O'Connell LY, Hong K, Meng YG, Weikert SH, Presta LG: Lack of fucose on human IgG1 N-linked oligosaccharide improves binding to human Fcgamma RIII and antibody-dependent cellular toxicity. J Biol Chem 2002, 277:26733-26740.

9. Shinkawa T, Nakamura K, Yamane N, Shoji-Hosaka E, Kanda Y, Sakurada M, Uchida K, Anazawa H, Satoh M, Yamasaki M, Hanai N, Shitara K: The absence of fucose but not the presence of galactose or bisecting $\mathrm{N}$ acetylglucosamine of human IgG1 complex-type oligosaccharides shows the critical role of enhancing antibody-dependent cellular cytotoxicity. J Biol Chem 2003, 278:3466-3473.

10. Niwa R, Hatanaka S, Shoji-Hosaka E, Sakurada M, Kobayashi Y, Uehara A, Yokoi H, Nakamura K, Shitara K: Enhancement of the antibody-dependent cellular cytotoxicity of low-fucose IgG1 is independent of Fcgam-maRIlla functional polymorphism. Clin Cancer Res 2004, 10:6248-6255.

11. Schenerman MA, Hope JN, Kletke C, Singh JK, Kimura R, Tsao El, FolenaWasserman G: Comparability testing of a humanized monoclonal antibody (SynagisR) to support cell line stability, process validation, and scale-up for manufacturing. Biologicals 1999, 27:203-215.

12. Kamoda S, Nomura C, Kinoshita M, Nishiura S, Ishikawa R, Kakehi K, Kawasaki N, Hayakawa T: Profiling analysis of oligosaccharides in antibody pharmaceuticals by capillary electrophoresis. J Chromatogr A 2004, 1050:211-216.

13. Miyoshi E, Noda K, Yamaguchi Y, Inoue S, Ikeda Y, Wang W, Ko JH, Uozumi N, Li W, Taniguchi N: The alpha1-6-fucosyltransferase gene and its biological significance. Biochim Biophys Acta 1999, 1473:9-20.

14. Tonetti M, Sturla L, Bisso A, Benatti U, De FA: Synthesis of GDP-L-fucose by the human FX protein. J Biol Chem 1996, 271:27274-27279.

15. Becker DJ, Lowe JB: Fucose: biosynthesis and biological function in mammals. Glycobiology 2003, 13:41R-53R.

16. Puglielli $L$, Hirschberg CB: Reconstitution, identification, and purification of the rat liver Golgi membrane GDP-fucose transporter. J Biol Chem 1999, 274:35596-35600

17. de Vries T, Knegtel RM, Holmes EH, Macher BA: Fucosyltransferases: structure/function studies. Glycobiology 2001, 11:119R-128R.

18. Ma B, Simala-Grant JL, Taylor DE: Fucosylation in prokaryotes and eukaryotes. Glycobiology 2006, 16:158R-184R.

19. Yamane-Ohnuki N, Kinoshita S, Inoue-Urakubo M, Kusunoki M, lida S, Nakano R, Wakitani M, Niwa R, Sakurada M, Uchida K, Shitara K, Satoh M: Establishment of FUT8 knockout Chinese hamster ovary cells: an ideal host cell line for producing completely defucosylated antibodies with enhanced antibody-dependent cellular cytotoxicity. Biotechnol Bioeng 2004, 87:614-622.

20. Kanda $Y$, Imai-Nishiya $H$, Kuni-Kamochi $R$, Mori K, Inoue M, KitajimaMiyama K, Okazaki A, lida S, Shitara K, Satoh M: Establishment of a GDPmannose 4,6-dehydratase (GMD) knockout host cell line: a new strategy for generating completely non-fucosylated recombinant therapeutics. $J$ Biotechnol 2007, 130:300-310.

21. Imai-Nishiya H, Mori K, Inoue M, Wakitani M, lida S, Shitara K, Satoh M: Double knockdown of alpha1,6-fucosyltransferase (FUT8) and GDPmannose 4,6-dehydratase (GMD) in antibody-producing cells: a new strategy for generating fully non-fucosylated therapeutic antibodies with enhanced ADCC. BMC Biotechnol 2007, 7:84.

22. Mori K, Kuni-Kamochi R, Yamane-Ohnuki N, Wakitani M, Yamano K, Imai H, Kanda Y, Niwa R, lida S, Uchida K, Shitara K, Satoh M: Engineering Chinese hamster ovary cells to maximize effector function of produced antibodies using FUT8 siRNA. Biotechnol Bioeng 2004, 88:901-908.

23. Beuger $V$, Künkele KP, Koll $H$, Gärtner $A$, Bähner $M$, Burtscher $H$, Klein $C$ : Short-hairpin-RNA-mediated silencing of fucosyltransferase 8 in Chinesehamster ovary cells for the production of antibodies with enhanced antibody immune effector function. Biotechnol Appl Biochem 2009, 53:31-37.

24. Kanda Y, Yamada T, Mori K, Okazaki A, Inoue M, Kitajima-Miyama K, KuniKamochi R, Nakano R, Yano K, Kakita S, Shitara K, Satoh M: Comparison of biological activity among nonfucosylated therapeutic $\lg \mathrm{G} 1$ antibodies 
with three different $\mathrm{N}$-linked Fc oligosaccharides: the high-mannose, hybrid, and complex types. Glycobiology 2007, 17:104-118.

25. Tojo S, Okazaki A, Wakitani M, Shinkawa T, Uchida K, Suzawa T: A chromatographic approach for elevating the antibody-dependent cellular cytotoxicity of antibody composites. Biol Pharm Bull 2009, 32:1604-1608.

26. Ripka J, Adamany A, Stanley P: Two Chinese hamster ovary glycosylation mutants affected in the conversion of GDP-mannose to GDP-fucose. Arch Biochem Biophys 1986, 249:533-545.

27. Kanda Y, Yamane-Ohnuki N, Sakai N, Yamano K, Nakano R, Inoue M, Misaka H, lida S, Wakitani M, Konno Y, Yano K, Shitara K, Hosoi S, Satoh M: Comparison of cell lines for stable production of fucose-negative antibodies with enhanced ADCC. Biotechnol Bioeng 2006, 94:680-688.

28. Sibéril S, de Romeuf $C$, Bihoreau N, Fernandez N, Meterreau JL, Regenman A, Nony E, Gaucher C, Glacet A, Jorieux S, Klein P, Hogarth MP, Fridman WH, Bourel D, Béliard R, Teillaud JL: Selection of a human antiRhD monoclonal antibody for therapeutic use: impact of lgG glycosylation on activating and inhibitory Fc gamma R functions. Clin Immunol 2006, 118:170-179.

29. Quandt K, Frech K, Karas H, Wingender E, Werner T: MatInd and MatInspector: new fast and versatile tools for detection of consensus matches in nucleotide sequence data. Nucleic Acids Res 1995, 23:4878-4884.

30. Lui X, Gorovsky MA: Mapping the $5^{\prime}$ and $3^{\prime}$ ends of Tetrahymena thermophila mRNAs using RNA ligase mediated amplification of CDNA ends (RLM-RACE). Nucleic Acids Res 1993, 21:4954-4960.

31. Kozak M: Regulation of translation in eukaryotic systems. Annu Rev Cell Biol 1992, 8:197-225.

32. Uchida S, Tanaka Y, Ito H, Saitoh-Ohara F, Inazawa J, Yokoyama KK, Sasaki S, Marumo F: Transcriptional regulation of the CLC-K1 promoter by mycassociated zinc finger protein and kidney-enriched Krüppel-like factor, a novel zinc finger repressor. Mol Cell Biol 2000, 20:7319-7131.

33. Martinez-Duncker I, Michalski JC, Bauvy C, Candelier JJ, Mennesson B, Codogno P, Oriol R, Mollicone R: Activity and tissue distribution of splice variants of alpha6-fucosyltransferase in human embryogenesis. Glycobiology 2004, 14:13-25.

34. Martinez-Duncker I, Mollicone R, Candelier JJ, Breton C, Oriol R: A new superfamily of protein-O-fucosyltransferases, alpha2-fucosyltransferases, and alpha6-fucosyltransferases: phylogeny and identification of conserved peptide motifs. Glycobiology 2003, 13:1C-5C.

35. Kessler N, Aymard M, Bertrand S: Stability of a murine hybridoma is dependent on the clonal line and culture media. In Vitro Cell Dev Biol 1993, 29:203-207.

36. Suzuki Y, Taira H, Tsunoda T, Mizushima-Sugano J, Sese J, Hata H, Ota T, Isogai T, Tanaka T, Morishita S, Okubo K, Sakaki Y, Nakamura Y, Suyama A, Sugano S: Diverse transcriptional initiation revealed by fine, large-scale mapping of mRNA start sites. EMBO Rep 2001, 2:388-393.

37. Yamaguchi Y, Ikeda Y, Takahashi T, Ihara H, Tanaka T, Sasho C, Uozumi N, Yanagidani S, Inoue S, Fujii J, Taniguchi N: Genomic structure and promoter analysis of the human alpha1, 6-fucosyltransferase gene (FUT8). Glycobiology 2000, 10:637-643.

38. Taniguchi A: Promoter structure and transcriptional regulation of human $\beta$-galactoside a2,3-sialyltransferase genes. Curr Drug Targets 2008, 9:310-316

39. Yan QW, Reed E, Zhong XS, Thornton K, Guo Y, Yu JJ: MZF1 possesses a repressively regulatory function in ERCC1 expression. Biochem Pharmacol 2006, 71:761-771.

40. Delogu A, Schebesta A, Sun Q, Aschenbrenner K, Perlot T, Busslinger M: Gene repression by Pax5 in B cells is essential for blood cell homeostasis and is reversed in plasma cells. Immunity 2006, 24:269-281.

41. Nagare T, Sakaue H, Takashima M, Takahashi K, Gomi H, Matsuki Y, Watanabe E, Hiramatsu R, Ogawa W, Kasuga M: The Krüppel-like factor KLF15 inhibits transcription of the adrenomedullin gene in adipocytes. Biochem Biophys Res Commun 2009, 379:98-103.

42. Otteson DC, Liu Y, Lai H, Wang C, Gray S, Jain MK, Zack DJ: Kruppel-like factor 15, a zinc-finger transcriptional regulator, represses the rhodopsin and interphotoreceptor retinoid-binding protein promoters. Invest Ophthalmol Vis Sci 2004, 45:2522-2530.

43. Tamura T, Yanai H, Savitsky D, Taniguchi T: The IRF Family Transcription Factors in Immunity and Oncogenesis. Annu Rev Immunol 2008, 26:535-584.
44. Lord CA, Savitsky D, Sitcheran R, Calame K, Wright JR, Ting JP, Williams KL: Blimp-1/PRDM1 mediates transcriptional suppression of the NLR gene NLRP12/Monarch-1. J Immunol 2009, 182:2948-2958.

45. Nakatani T, Mizuhara E, Minaki Y, Sakamoto Y, Ono Y: Helt, a novel BasicHelix-Loop transcriptional repressor expressed in the developing Central Nervous System. J Biol Chem 2004, 279:16356-16367.

46. Nepveu A: Role of the multifunctional CDP/Cut/Cux homeodomain transcription factor in regulating differentiation, cell growth and development. Gene 2001, 270:1-15.

47. Goyama S, Nitta E, Yoshino T, Kako S, Watanabe-Okochi N, Shimabe M, Imai Y, Takahashi K, Kurosawa M: EVI-1 interacts with histone methyltransferases SUVH and G9a for transcriptional repression and bone marrow immortalization. Leukemia 2010, 24:81-88.

48. Qiu Y, Lynch J, Guo L, Yatsula B, Perkins A, Michalak M: Regulation of calreticulin gene by GATA6 and EVI-1 transcription factors. Biochemistry 2008, 47:3697-3704.

49. Holmes K, Song J, Liu X, Brown M, Carroll J: Nkx3-1 and LEF-1 function as transcriptional inhibitors of estrogen receptor activity. Cancer Res 2008, 68:7380-7385.

50. Georgopoulos K, Winandy S, Avitahl N: The role of the Ikaros gene in lymphocyte development and homeostasis. Annu Rev Immunol 1997, 15:155-176.

51. Hock H, Orkin S: Zinc finger transcription factor Gfi-1: versatile regulator of lymphocytes, neutrophils and hematopoietic stem cells. Curr Opin Hematol 2006, 13:1-6.

52. Du JX, Bialkowska AB, McConnell BB, Yang VW: SUMOylation regulates nuclear localization of Krüppel-like factor 5. J Biol Chem 2008, 283:31991-32002.

53. Livak KJ, Schmittgen TD: Analysis of relative gene expression data using real-time quantitative PCR and the 2(-Delta Delta $C(T)$ ) Method. Methods 2001, 25:402-408.

doi:10.1186/1472-6750-11-1

Cite this article as: Teylaert et al: Molecular cloning, characterization, genomic organization and promoter analysis of the $\alpha 1,6-$-fucosyltransferase gene (fut8) expressed in the rat hybridoma cell line YB2/O. BMC Biotechnology 2011 11:1.

\section{Submit your next manuscript to BioMed Central and take full advantage of:}

- Convenient online submission

- Thorough peer review

- No space constraints or color figure charges

- Immediate publication on acceptance

- Inclusion in PubMed, CAS, Scopus and Google Scholar

- Research which is freely available for redistribution 